\title{
PENYELESAIAN PERSELISIHAN HASIL PEMILIHAN KEPALA DAERAH PASCA PUTUSAN MK NO. 97/PUU-XI.2013
}

\author{
(Resolving Disputes on Electoral Result from the Local Election for Regional Leaders \\ after the Verdict of the Constitutional Court No.97/PUU-XI.2013)
}

\author{
Indra Hendrawan \\ Pusat Perencanaan Pembangunan Hukum Nasional \\ Badan Pembinaan Hukum Nasional \\ Jl. Mayjen Sutoyo No. 10 Cililitan Jakarta Timur \\ Email: indra.hukumham@gmail.com
}

Naskah diterima: 19 Januari 2015; revisi: 24 April 2015; disetujui: 30 April 2015

\begin{abstract}
Abstrak
Undang-Undang Nomor 1 Tahun 2015 tentang Penetapan Perpu Nomor 1 Tahun 2014 tentang Pemilihan Gubernur, Bupati dan Walikota Menjadi Undang-Undang mengamanatkan Mahkamah Agung sebagailembaga yang berwenang menyelesaikan perselisihan hasil pemilihan kepala daerah. Namun tanpa sempat diimplementasikan, Undang-Undang tersebut telah direvisi kembali melalui Undang-Undang Nomor 8 Tahun 2015 dengan melimpahkan penyelesaian perselisihan hasil pemilihan ke badan peradilan khusus. Perubahan Undang-Undang secara cepat tersebut telah menimbulkan pertanyaan, kemanakah arah kebijakan penyelesaian perselisihan di masa mendatang? Dengan pendekatan yuridis normative, tulisan ini mencoba menguraikan refleksi penyelesaian perselisihan di Mahkamah Agung ataupun Mahkamah Konstitusi selama satu dasawarsa terakhir untuk mendapatkan penanganan ideal yang harus dilakukan dalam rangka perbaikan penanganan perselisihan hasil pemilihan kepala daerah di masa mendatang. Berdasarkan hal tersebut, penempatan hakim-hakim yang berintegritas, mumpuni serta yang mengedepankan keadilan substantif dalam penyelesaian perselisihan merupakan hal mutlak yang harus dilakukan. Selain itu, perbaikan juga tidak cukup hanya pada tahap penanganan perselisihan hasil saja, perlu pula ada optimalisasi penegakan hukum di tahap-tahap sebelumnya yang dilakukan oleh KPU, Bawaslu/Panwaslu, DKPP ataupun penegak hukum lainnya.
\end{abstract}

Kata kunci: penyelesaian perselisihan, pemilihan kepala daerah, keadilan

\begin{abstract}
Law No. 1 of 2015 on Enactment of Government Regulation in Lieu of Law No. 1 of 2014 concerning the election of Governor, the Regent and Mayor Become Law mandates the Supreme Court as an authorized institution to settle disputes about electoral result from the local election for regional leaders. However, without a chance to be implemented, the Law has been revised by Law No. 8 of 2015 in which any disputes that arise from the results of the election are delegated to a special judicial body. The ammendment has raised question, to where the policy of dispute resolution will be directed in the future? Using normative juridical approach, this paper tries to elaborate the reflection of dispute resolution in the Supreme Court or the Constitutional Court during the last decade to find out ideal treatment should be applied in order to improve the dispute resolution mechanism in the future. So, the placement of judges who have integrity, capability, and put the substantive fairness in the dispute resolution is absolute term. In addition, the improvement is not enough in just handling the dispute resolution stage, there should also be optimizing of the the law enforcement in the earlier stages that were carried out by the General Election Commission, Bawaslu/Panwaslu, DKPP or other law enforcement bodies.
\end{abstract}

Keywords: dispute, local elections for regional leaders, justice 


\section{A. Pendahuluan}

Penangkapan

Ketua

Mahkamah

Konstitusi (MK) Akil Mochtar terkait suap perselisihan hasil pemilihan kepala daerah telah menghancurkan wibawa MK sebagai penjaga konstitusi. Kepentingan politik dan ekonomi yang begitu kental menjadi tantangan tersendiri bagi siapapun yang menangani perselisihan hasil pemilihan. MK sebagai produk hasil reformasi yang sempat diagungagungkan independensinya tidak mampu untuk mengatasi rawannya perkara dari "permainan kotor". Para pihak yang berperkara berusaha menyuap hakim yang memeriksa perkara untuk memenangkan pemilihan walaupun harus mengeluarkan modal yang banyak.

Penanganan perkara pemilihan kepala daerah kembali berpolemik ketika MK mengabulkan permohonan tentang pengujian Pasal 236C Undang-Undang Nomor 12 Tahun 2008 tentang Pemerintahan Daerah dan Pasal 29 ayat (1) huruf e Undang-Undang Nomor 48 Tahun 2009 tentang Kekuasaan Kehakiman terkait kewenangan MK mengadili perselisihan hasil Pilkada. Pengujian ini berakhir dengan putusan MK No. 97/PUU-XI.2013 yang mengabulkan seluruh permohonan para pemohon walaupun disertai dengan dissenting opinion dari 3 (tiga) hakim MK lainnya.

MK menilai bahwa kedua pasal itu bertentangan dengan UUD NRI Tahun 1945. Penambahan kewenangan MK untuk mengadili perselisihan hasil pemilihan kepala daerah dengan memperluas makna pemilu seperti diatur Pasal 22E UUD NRI Tahun 1945 adalah inkonstitusional. Pemilu menurut Pasal 22E UUD NRI Tahun 1945 harus dimaknai secara limitatif untuk memilih anggota DPR, DPD, DPRD, presiden dan wakil presiden yang dilaksanakan lima tahun sekali, jika memasukkan pemilihan kepala daerah menjadi bagian dari pemilu dan menjadi kewenangan MK maka tidak sesuai dengan makna original intent dari pemilu.

Undang-Undang Nomor 1 Tahun 2015 tentang Penetapan Perpu No 1 Tahun 2014 tentang Pemilihan Gubernur, Bupati dan Walikota Menjadi Undang-Undang seolah menjadi jawaban atas ketidakpastian lembaga manakah yang berwenang menyelesaikan perselisihan hasil Pilkada. Pasal 159 menyatakan bahwa penyelesaian perselisihan hasil pemilihan ditangani oleh hakim adhoc di Pengadilan Tinggi yang ditetapkan oleh Mahkamah Agung (MA). Berdasarkan pasal tersebut, Undang-Undang menghendaki lembaga yang berwenang untuk menyelesaikan perselisihan hasil Pilkada adalah MA.

Penafsiran Pasal 22E UUD NRI Tahun 1945 memang sulit untuk mempertahankan penanganan perselisihan tetap berada di MK, mengingat wewenang dan kewajiban MK secara rinci dan limitative diatur dalam konstitusi sehingga tidak ada lagi peluang penambahan atau pengurangan wewenang MK melalui peraturan perundang-undangan dibawah konstitusi, berbeda dengan MA yang wewenangnya masih terbuka untuk ditambah melalui Undang-Undang ${ }^{1}$. Putusan MK juga harus dihormati sebagai Putusan yang final dan mengikat apapun perdebatannya, apabila kewenangan ingin dikembalikan lagi ke MK, harus ada Putusan MK kembali yang menyatakan dirinya berwenang atau terlebih dahulu harus ada amandemen UUD NRI Tahun 
1945 yang memperjelas "gender" pemilihan kepala daerah.

Keberlakuan Undang-Undang Nomor 1 Tahun 2015 ternyata tidak berlangsung lama, pada tanggal 18 Februari 2015 rapat paripurna DPR merevisi Undang-Undang tersebut melalui Undang-Undang Nomor 8 Tahun 2015. Kini, perkara perselisihan hasil pemilihan diperiksa dan diadili oleh badan peradilan khusus, selama badan peradilan khusus tersebut belum terbentuk maka penanganan perkara perselisihan hasil pemilihan dilakukan oleh MK. Dengan saling berpindahnya kewenangan lembaga yang berhak menangani perselisihan hasil pemilihan menjadi pertanyaan besar kemanakah arah kebijakan penanganan sengketa hasil pemilihan ini?, apakah di MK atau MA ataukah badan peradilan khusus?

Penanganan perselisihan pemilihan menjadi menarik untuk dikaji mengingat perkara ini bukanlah hal yang baru dalam pengalaman hukum bangsa ini, perselisihan hasil pemilihan telah satu dasawarsa ditangani baik oleh MA ataupun MK, oleh karena itu banyak pembelajaran yang dapat dipetik dari pengalaman tersebut. Apakah MK atau MA atau badan peradilan khusus yang menangani perselisihan hasil pemilihan, hal yang penting dari semua itu adalah harus ada perbaikan model penyelesaian perselisihan hasil pemilihan kepala daerah.

Berdasarkan hal tersebut, akan dibahas lebih jauh tentang bagaimanakah gambaran/ refleksi penanganan perselisihan hasil pemilihan kepala daerah selama satu dasawarsa terakhir? serta bagaimanakah lembaga dan optimalisasi penanganan ideal yang harus dilakukan dalam rangka perbaikan penanganan perselisihan hasil pemilihan kepala daerah di masa mendatang.

\section{B. Metode Penelitian}

Berdasarkan ruang lingkup masalah sebagaimana telah diuraikan, penelitian ini menggunakan tipe penelitian yuridis normative (normative legal research), yaitu penelitian yang ditujukan untuk meneliti asas-asas hukum, sistematika hukum, sinkronisasi peraturan perundang-undangan secara vertical dan horizontal, perbandingan hukum dan sejarah hukum², dengan demikian penelitian ini menitikberatkan pada alat pengumpulan data sekunder berupa studi dokumen atau bahan pustaka.

Bahan hukum yang digunakan sebagai sumber utama yaitu bahan hukum primer berupa peraturan perundang-undangan dan yurisprudensi antara lain peraturan perundangundangan terkait pemilihan kepala daerah serta Putusan Mahkamah Agung dan Putusan Mahkamah Konstitusi yang terkait dengan penanganan perselisihan hasil pemilihan kepala daerah. Sedangkan bahan hukum sekunder yang digunakan yaitu buku-buku, karya ilmiah dan hasil penelitian yang berkaitan dengan objek yang dibahas. Pengumpulan data dilengkapi pula dengan artikel hukum dari internet ataupun artikel ilmiah lainnya yang dapat mendukung pengayaan data dalam penelitian ini. Pengolahan data atau analisa dilakukan secara kualitatif dimana penyajian data dilakukan sekaligus dengan analisanya ${ }^{3}$.

Soerjono Soekanto, Pengantar Penelitian Hukum, (Jakarta, UI Press, 2010), hal 40.

Ibid, hal 41. 


\section{Pembahasan}

1. Refleksi Satu Dasawarsa Penyelesaian Perselisihan Hasil Pilkada

a. Penanganan Sengketa Hasil Pilkada berdasarkan Undang-Undang Nomor 32 Tahun 2004 tentang Pemerintahan Daerah

\section{1) Pengaturan Hukum Penyelesaian Sengketa Hasil Pilkada}

Sejak berlakunya Undang-Undang Nomor 32 Tahun 2004 tentang Pemerintahan Daerah, pilkada pertama kali diselenggarakan pada bulan Juni 2005. Terkait penanganan sengketa hasil pilkada, pengaturannya didasarkan Pasal 106 Undang-Undang Nomor 32 Tahun 2004 Tentang Pemerintahan Daerah, yang berisi:

ayat (1): keberatan terhadap penetapan hasil pemilihan kepala daerah dan wakil kepala daerah hanya dapat diajukan oleh pasangan calon kepada Mahkamah Agung dalam waktu paling lambat 3 (tiga) hari setelah penetapan hasil pemilihan kepala daerah dan wakil kepala daerah.

ayat (2): keberatan sebagaimana dimaksud pada ayat (1) hanya berkenaan dengan hasil perhitungan suara yang mempengaruhi terpilihnya pasangan.

ayat (3): pengajuan keberatan kepada Mahkamah Agung sebagaimana dimaksud pada ayat (1) disampaikan kepada pengadilan tinggi untuk pemilihan kepala daerah dan wakil kepala daerah provinsi dan kepada pengadilan negeri untuk pemilihan kepala daerah dan wakil kepala daerah kabupaten/kota.

ayat (4): Mahkamah Agung memutus perselisihan hasil penghitungan suara sebagaimana dimaksud pada ayat (1) dan ayat (2) paling lambat 14 (empat belas) hari sejak diterimanya permohonan keberatan oleh Pengadilan Negeri/ Pengadilan Tinggi/Mahkamah Agung. ayat (5): Putusan Mahkamah Agung sebagaimana dimaksud pada ayat (4) bersifat final dan mengikat.

ayat (6): Mahkamah Agung dalam melaksanakan kewenangannya sebagaimana dimaksud pada ayat (1) dapat mendelegasikan kepada Pengadilan Tinggi untuk memutus perselisihan perhitungan suara pemilihan kepala daerah dan wakil kepala daerah kabupaten dan kota.

Dalam peraturan pelaksanaannya, ketentuan Pasal 106 tersebut kembali diulang secara utuh dalam Pasal 94 PP No. 6 Tahun 2005 Tentang Pemilihan, Pengesahan, Pengangkatan dan Pemberhentian Kepala Daerah dan Wakil Kepala Daerah. Sedangkan mengenai prosedur acara pemeriksaan di MA maupun Pengadilan Tinggi diatur dalam Perma No. 2 Tahun 2005 tentang Tata Cara Pengajuan Upaya Hukum Keberatan terhadap Penetapan Hasil Pilkada dan Pilwakada Dari KPUD Provinsi dan KPUD Kabupaten/Kota.

Pengajuan upaya hukum keberatan di dalam Pasal 3 ayat (1) Perma No.2 Tahun 2005 berbunyi "Keberatan terhadap penetapan hasil pemilihan kepala daerah dan wakil kepala daerah provinsi atau kab/kota hanya dapat diajukan berkenaan dengan hasil penghitungan suara yang mempengaruhi terpilihnya pasangan calon", kemudian di dalam ayat (5) memperjelas bahwa "Keberatan yang diajukan oleh pemohon atau kuasa hukumnya wajib menguraikan dengan jelas dan rinci tentang:

a) Kesalahan dari penghitungan suara yang diumumkan oleh KPUD dan hasil penghitungan suara yang benar menurut pemohon;

b) Permintaan untuk membatalkan hasil penghitungan suara yang diumumkan KPUD dan menetapkan hasil penghitungan suara yang benar menurut pemohon; 
Terkait dengan putusan yang dapat dikeluarkan oleh Mahkamah Agung atau Pengadilan Tinggi diatur di dalam Pasal 4 bahwa Putusan berisi:

a) Permohonan keberatan tidak dapat diterima;

b) Menolak permohonan keberatan;

c) Mengabulkan permohonan keberatan dengan menyatakan membatalkan hasil penghitungan suara yang ditetapkan oleh KPUD dan menetapkan hasil perhitungan suara yang benar ${ }^{4}$.

Penanganan sengketa hasil pilkada selama ditangani oleh MA telah menyelesaikan sebanyak 98 perkara, yang terdiri dari 74 perkara kasasi dan 24 perkara peninjauan kembali (PK). Perkara tersebut diselesaikan sejak tahun 2005 hingga 2008. Dari jumlah tersebut, hanya empat perkara yang permohonannya dikabulkan MA. Sisanya ditolak 5 .

Secara umum, permohonan yang ditolak adalah karena pemohon tidak pernah mampu membuktikan adanya kesalahan penghitungan suara. Banyak permohonan diajukan dengan alasan yang berada di luar kompetensi pengadilan berupa pelanggaran-pelanggaran yang sudah dilakukan sejak awal proses pentahapan pilkada, seperti:

a) Surat suara yang tidak didistribusikan kepada yang berhak;

b) Menghalangi massa atau pendukung calon tertentu untuk menggunakan hak pilihnya;

c) Tidak membagikan kartu pemilih dan surat panggilan untuk memilih; d) Para calon telah memberikan iming-iming uang kepada para pemilihnya (money politic) dan janji-janji tertentu (kontrak politik);

e) Pelanggaran saat kampanye;

f) Pembakaran surat suara;

g) Pencoblosan surat suara oleh anak-anak dibawah umur untuk menggelembungkan jumlah suara ${ }^{6}$.

\section{2) Contoh Kasus Penanganan Sengketa Hasil Pilkada di MA.}

Penanganan sengketa yang dilakukan oleh MA terbatas pada penyelesaian sengketa hasil pilkada serta dengan tegas menolak untuk mengadili sengketa diluar dari hasil pilkada, di dalam Undang-Undang Nomor 32 Tahun 2004 telah jelas disebut bahwa keberatan itu berkenaan dengan penghitungan suara yang mempengaruhi terpilihnya pasangan calon saja, karena itu pemeriksaan hanya diarahkan pada persoalan rekapitulasi penghitungan suara tersebut.

Salah satu contoh yang cukup menarik dari putusan hasil penyelesaian sengketa tersebut adalah penyelesaian sengketa hasil pilkada Kota Depok. Surat Penetapan dari KPUD Depok No.18 Tahun 2005 telah memenangkan pasangan calon Nur Mahmudi-Yuyun dengan hasil rekapitulasi KPUD untuk pasangan Nur Mahmudi-Yuyun sebesar 232.610 suara sedangkan pasangan Badrul-Syihabudin sebesar 206.781 suara, selisih diantara mereka adalah sebesar 25.829 suara.

Pasangan calon Walikota Badrul-Syihabudin menyatakan keberatannya dengan mengajukan

$4 \quad$ Peraturan Mahkamah Agung No.2 Tahun 2005.

$5 \quad$ Hukumonline.com, MA resmi limpahkan sengketa hasil pilkada ke MK, diakses tanggal 5 Januari 2014.

6 Paulus Effendi Lotulung, Aspek Yuridis dalam masalah Sengketa Pilkada, (LPP HAN, 2005), hal x. 
perkara tersebut ke Pengadilan Tinggi Jawa Barat. Atas dasar pengajuan permohonan sengketa hasil pilkada, Pengadilan Tinggi Jabar dalam amar putusannya memutuskan?:

a) mengabulkan permohonan dari Pemohon (Badrul-Syihabudin).

b) menyatakan batal hasil perhitungan suara akhir yang diumumkan oleh KPUD Depok.

c) Menyatakan jumlah perhitungan yang benar adalah: Untuk calon pasangan Nomor 3 (Badrul-Syihabudin) perolehan suara menjadi 269.551 suara dan untuk calon pasangan Nomor 5 (Nur Mahmudi-Yuyun) perolehan suara menjadi 204.828 suara.

Hasil putusan ini mengundang banyak polemik baik dari kalangan politik, praktisi ataupun akademis, putusan dari Pengadilan Tinggi Jabar dinilai tidak berdasarkan hukum dan fakta, putusan itu cacat hukum secara formal dan materiil sehingga harus dikatakan batal demi hukum.

Pada dasarnya pemeriksaan keberatan penghitungan hasil suara di Pengadilan Tinggi Jabar diajukan dengan alasan yang hampir serupa dengan kasus perselisihan pilkada lainnya, tetapi yang menarik pada kasus ini Pengadilan Tinggi mengabulkan permohonan yang diajukan. Pengadilan menyatakan sekitar 60.000 suara yang diklaim pemohon (BadrulSyihabudin) disetujui tanpa lebih dulu ada pemeriksaan yang pasti apakah suara itu memang benar memilih pemohon. Oleh karena itu, disinyalir dalam persidangan ini terdapat penyimpangan prosedur beracara.

Atas dasar berbagai kejanggalan tersebut pihak Nur Mahmudi-Yuyun mengajukan upaya hukum luar biasa Peninjauan Kembali ke MA, namun menjadi pertanyaan pada saat itu, apakah Putusan Pengadilan Tinggi Jabar dapat diperiksa mengingat berdasarkan Undang-Undang Nomor 32 Tahun 2004, PP No.6 tahun 2005 dan Perma No.2 Tahun 2005, keseluruhannya menyebutkan bahwa putusan Pengadilan Tinggi bersifat Final dan Mengikat.

Menjawab polemik tersebut, pada akhirnya MA berpendapat bahwa pengajuan tersebut dapat dibenarkan dan mengabulkan permohonan PK karena Pengadilan Tinggi dinilai telah melakukan kekeliruan dalam menerapkan hukum, dengan alasan sebagai berikut ${ }^{8}$ :

a) Bahwa yang menjadi wewenang MA atau Pengadilan Tinggi dalam memeriksa dan mengadili perselisihan hasil Pilkada adalah hanya terhadap penetapan hasil pemilihan yang berkenaan dengan hasil penghitungan suara yang mempengaruhi terpilihnya pasangan calon.

b) Bahwa konsekuensi diajukan keberatan dalam perselisihan hasil Pilkada adalah kewajiban dari Pemohon untuk membuktikan adanya kehilangan suara Pemohon, pembuktian tersebut tentunya harus berdasarkan alat bukti yang sah dan menurut hukum acara perdata, bukan berdasarkan pada dugaan atau asumsi yang tidak dapat menjadi alat bukti yang sempurna, hasil akhir penghitungan suara tidak dapat digagalkan oleh hal-hal yang bersifat teknis dalam pelaksanaan pemilihan karena tentang hal tersebut bukan merupakan wewenang MA untuk menyelesaikannya.

c) Bahwa alat-alat bukti yang diajukan oleh Termohon Peninjauan Kembali menurut pendapat MA selain tidak ada yang dapat

Putusan Pengadilan Tinggi Jawa Barat No.01/PILKADA/2005/PT.Bdg.

$8 \quad$ Putusan Mahkamah Agung Nomor 01 PK/PILKADA/2005. 
membuktikan adanya kehilangan suara yang signifikan yang dapat mempengaruhi penetapan hasil penghitungan suara, selain itu alat bukti tersebut hanya berkenaan dengan teknis dalam penyelenggaraan pemilihan, yang untuk memeriksa dan memutusnya bukan menjadi wewenang MA maupun Pengadilan Tinggi.

Pada prinsipnya, langkah yang telah diambil MA untuk menyidangkan Peninjauan Kembali perselisihan hasil pilkada Kota Depok merupakan terobosan hukum dalam rangka menjaga rasa keadilan di dalam masyarakat, selain itu MA juga menjaga garis ketentuan bahwa penyelesaian perselisihan yang dapat diadili oleh Pengadilan Tinggi ataupun MA hanyalah yang terkait dengan perselisihan hasil suara pemilihan, lebih dari itu yang terkait dengan penyelenggaraan pemilihan bukanlah menjadi kewenangan Pengadilan Tinggi ataupun $M A$, prinsip ini yang menurut MA telah terjadi "kesalahan yang nyata" dalam menerapkan hukum yang telah dilakukan oleh Pengadilan Tinggi Jabar dalam menangani perselisihan hasil pilkada Kota Depok.

Contoh kasus lain yang dapat mempertegas karakteristik model penyelesaian perselisihan di MA dapat pula dilihat pada kasus pilkada provinsi Sulawesi Selatan. Putusan Kasasi MA No.02P/KPUD/2007 telah memerintahkan pemungutan suara ulang di 4 kabupaten di Sulawesi Selatan. Namun demikian, melalui Putusan PK, MA menganulir pelaksanaan pemungutan suara ulang yang telah dilakukan tersebut. MA menganggap putusan tersebut sebagai "kesalahan yang nyata" yang telah dilakukan oleh Majelis Hakim. Putusan yang dapat dikeluarkan oleh MA terkait penanganan perselisihan hasil pilkada hanya dapat berupa permohonan keberatan tidak dapat diterima, mengabulkan permohonan atau menolak permohonan.

b. Penanganan Perselisihan Hasil Pilkada berdasarkan Undang-Undang Nomor 12 Tahun 2008 tentang Perubahan Kedua Undang-Undang Nomor 32 Tahun 2004 tentang Pemerintahan Daerah.

\section{1) Pengaturan Hukum Penyelesaian Perselisihan Hasil Pilkada}

Pembahasan penanganan perselisihan hasil pilkada berdasarkan Undang-Undang Nomor 12 Tahun 2008 tidak dapat terlepas dari keberlakuan Undang-Undang Nomor 22 Tahun 2007 tentang Penyelenggara Pemilihan Umum. Berdasarkan Undang-Undang ini terjadi beberapa transformasi seputar hukum Pilkada, antara lain;

a) Pilkada (selanjutnya disebut Pilkada) dimasukkan dalam rezim pemilu, hal ini ditandai dengan dimasukkannya pengaturan mengenai pilkada di dalam Undang-Undang Nomor 22 Tahun 2007 sehingga secara resmi bernama Pemilihan Umum Kepala Daerah dan Wakil Kepala Daerah atau disingkat Pilkada.

b) Perubahan pemaknaan pilkada dari rezim Pemerintahan Daerah ke rezim pemilu di dalam Undang-Undang Nomor 22 Tahun 2007 membawa implikasi dikemudian hari dengan diserahkannya penanganan perselisihan hasil Pilkada dari MA ke MK melalui Undang-Undang Nomor 12 tahun 2008.

Secara umum, penanganan perselisihan hasil Pilkada, pengaturannya dilandasi berdasarkan Pasal 236 C Undang-Undang Nomor 12 Tahun 2008 tentang Pemerintahan Daerah, yang berisi: 
"Penanganan perselisihan hasil penghitungan suara pemilihan kepala daerah dan wakil kepala daerah oleh Mahkamah Agung dialihkan kepada Mahkamah Konstitusi paling lama 18 (delapan belas) bulan sejak UU ini diundangkan"

Dasar peralihan kewenangan penyelesaian perselisihan pilkada dari MA ke MK berdasarkan tinjauan dari sisi penyelenggara pemilu tercantum dalam Pasal 1 Butir 5 UndangUndang Nomor 22 Tahun 2007 yang berbunyi "Penyelenggara Pemilihan Umum adalah lembaga yang menyelenggarakan Pemilu untuk memilih anggota DPR,DPD, DPRD, Dan Presiden dan Wakil Presiden, serta kepala daerah dan wakil kepala daerah secara langsung oleh rakyat" selanjutnya di dalam Pasal 1 Butir 7 diperjelas kembali bahwa "Komisi Pemilihan Umum Provinsi dan Komisi Pemilihan Umum kabupaten/Kota, selanjutnya disebut KPU Provinsi dan KPU Kabupaten/Kota adalah Penyelenggara Pemilu di provinsi dan Kabupaten/Kota".

Sebelum Undang-Undang Nomor 22 Tahun 2007 diterbitkan, Pilkada diselenggarakan di bawah rezim pemerintahan daerah dan perselisihan hasil Pilkada diserahkan kepada MA. Setelah terbitnya Undang-Undang Penyelenggara Pemilu, Pilkada dianggap sebagai bagian dari pemilu, kewenangan penyelenggaraan Pilkada menjadi ranah dari KPU sehingga KPU berwenang untuk membuat regulasi tentang Pilkada di bawah Undang-Undang dan perselisihan Pilkada harus diserahkan dari MA ke MK. Peralihan kewenangan tersebut didasarkan pada Pasal 24C UUD NRI Tahun 1945 bahwa institusi yang memiliki kewenangan untuk memutus perselisihan tentang hasil pemilihan umum adalah Mahkamah Konstitusi.

Undang-Undang Nomor 12 Tahun 2008 tentang Perubahan Kedua Undang-Undang Nomor 32 Tahun 2004 tentang Pemerintahan Daerah sesungguhnya telah membawa semangat perubahan ini, oleh karena itu munculnya Pasal 236 C Undang-Undang Nomor 12 Tahun 2008 hanya untuk menegaskan sekaligus sebagai dasar hukum peralihan kewenangan penyelesaian perselisihan hasil Pilkada.

Teknis penyelesaian perselisihan hasil Pilkada tidak seluruhnya lagi diatur dalam PP No.6 Tahun 2005, tata cara penyelesaian perselisihan Pilkada kini diatur langsung melalui:

a) Hukum acara MK sebagaimana diatur dalam Undang-Undang Nomor 24 Tahun 2003, yang merupakan hukum acara yang bersifat umum di dalam MK;

b) Peraturan Mahkamah Konstitusi No 15 Tahun 2008 tentang Pedoman Beracara Dalam Perselisihan Hasil Pemilihan Umum Kepala Daerah yang merupakan hukum acara yang bersifat khusus.

\section{2) Contoh Kasus Penanganan Perselisihan Hasil Pilkada di MK}

Berdasarkan beberapa putusan yang telah dikeluarkan oleh MK terlihat jelas ada perubahan karakteristik secara mendasar antara penanganan perselisihan ketika masih ditangani oleh MA dan penanganan ketika sudah ditangani oleh MK.

Perbedaan karakter tersebut juga dapat dilihat dari makna pengujian yang berbeda antara dua institusi tersebut. MK melakukan pengujian konstitusionalitas (the constitutional 
of legislative law or legis/ation), sedangkan MA melakukan pengujian legalitas (the legality of regulation) ${ }^{9}$.

Salah satu contoh kasus yang dapat memberikan gambaran tersebut dapat dilihat dari Putusan Mahkamah Konstitusi No. 41/ PHPU.D-VI/2008 yang memutus perselisihan hasil perolehan suara dalam Pilkada provinsi Jawa Timur. Perselisihan tersebut secara ringkas mengenai pasangan Khofifah Indar Parawansa dan Mujiono (Kaji) yang menggugat hasil penghitungan suara pilgub Jatim oleh KPU Provinsi Jatim dengan hasil Khofifah-Mujiono (Kaji) 7.669.721 suara dan Soekarwo-Saifullah Yusuf (Karsa) 7.729.994 suara. Pemohon menilai terdapat kesalahan penghitungan suara secara sistematis di 25 kabupaten/kota di Jatim, dan mengklaim hasil yang benar adalah Kaji 7.654.742 suara dan Karsa 7.632.281 suara.

Amar putusan yang dikeluarkan oleh majelis hakim dalam persidangan tersebut adalah mengabulkan permohonan untuk sebagian, membatalkan dan menyatakan tidak mengikat secara hukum Keputusan KPU Provinsi Jawa Timur serta memerintahkan kepada KPU Provinsi Jawa Timur:

a) Pemungutan suara ulang Pemilu Kepala Daerah dan Wakil Kepala Daerah Prov. Jawa Timur Putaran II di Kab. Bangkalan dan Kab. Sampang dalam waktu paling lambat 60 hari sejak Putusan ini diucapkan;

b) Penghitungan suara ulang Pemilu Kepala Daerah dan Wakil Kepala Daerah Prov. Jawa Timur Putaran II di Kab. Pamekasan dengan menghitung kembali secara berjenjang surat suara yang sudah dicoblos dalam waktu paling lambat 30 hari sejak Putusan ini diucapkan ${ }^{10}$;

Perintah untuk melakukan penghitungan suara ulang ini sebelumnya tidak pernah diperkenankan ketika perselisihan pilkada masih ditangani oleh MA.

Berdasarkan pada kasus perselisihan Pilkada di Jawa Timur, menarik untuk dikaji bagaimana MK menilai permasalahan tersebut melalui ikhtisar pertimbangan hukum MK sebagai berikut ${ }^{11}$ :

a) Secara materiil telah terjadi pelanggaran ketentuan Pilkada yang berpengaruh terhadap perolehan suara kedua Pasangan Calon Kepala Daerah dalam Pilkada Provinsi Jawa Timur Putaran II;

b) Pelanggaran sistematis, terstruktur dan masif yang terjadi di daerah pemilihan Kab. Sampang, Kab. Bangkalan, dan Kab. Pamekasan yang bertentangan dengan konstitusi khususnya pelaksanaan Pilkada secara demokratis, terbukti secara sah dan meyakinkan, sehingga oleh karenanya Pasangan Calon yang terbukti melakukan pelanggaran tidak boleh diuntungkan oleh pelanggarannya, dan sebaliknya Pasangan Calon lainnya tidak boleh dirugikan;

c) Keputusan KPU Provinsi Jawa Timur tentang Rekapitulasi Hasil Penghitungan Suara Pilkada Provinsi Jawa Timur Putaran II harus dinyatakan batal dan tidak mempunyai kekuatan hukum mengikat sepanjang mengenai Hasil Penghitungan Suara di Kabupaten yang terkena dampak pengaruh pelanggaran dimaksud;

\footnotetext{
9 Jimly Asshiddiqie, Hukum Acara Pengujian Undang-Undang, (Jakarta: Yarsif Watampone, 2005), hlm. 5.

10 Putusan Mahkamah Konstitusi No. 41/PHPU.D-VI/2008.

11 Loc.cit.
} 
d) Dalam mengadili perkara ini, Mahkamah tidak dapat dipasung hanya oleh ketentuan UU yang ditafsirkan secara sempit, yakni bahwa Mahkamah hanya boleh menilai hasil Pilkada dan melakukan penghitungan suara ulang dari berita acara atau rekapitulasi yang dibuat secara resmi oleh KPU Provinsi Jawa Timur, sebab kalau hanya berpedoman pada hasil penghitungan suara formal yang dibuat oleh Termohon tidak mewujudkan kebenaran materiil sehingga akan sulit ditemukan keadilan;

e) Untuk menegakkan keadilan substantif dan untuk memberi manfaat dalam penegakan demokrasi dan konstitusi yang harus dikawal oleh Mahkamah, dengan mempertimbangkan semua alat bukti yang diajukan dalam persidangan, maka Mahkamah dapat memerintahkan pemungutan suara ulang dan/atau penghitungan suara ulang di kabupaten dan/atau bagian tertentu lainnya di wilayah pemungutan suara dalam perkara a quo;

f) Manfaat yang dapat diperoleh dari putusan yang demikian adalah agar pada masamasa yang akan datang, pemilihan umum pada umumnya dan Pilkada khususnya, dapat dilaksanakan dengan asas langsung, umum, bebas, rahasia, jujur, dan adil tanpa dicederai oleh pelanggaran serius, terutama yang sifatnya sistematis, terstruktur, dan masif. Pilihan Mahkamah yang demikian masih tetap dalam koridor penyelesaian perselisihan hasil Pilkada dan bukan penyelesaian atas proses pelanggarannya sehingga pelanggaran-pelanggaran atas

proses itu sendiri dapat diselesaikan lebih lanjut melalui jalur hukum yang tersedia;

g) Memerintahkan Termohon (KPU Provinsi Jawa Timur) untuk melaksanakan pemungutan suara ulang dan penghitungan suara ulang di Kabupaten yang akan disebut dalam amar putusan;

Pengalihan kewenangan dari MA ke MK telah memberi sifat dan karakter yang berbeda, disatu sisi undang-undang telah menegaskan bahwa kewenangan MK adalah memutus perselisihan tentang hasil pemilihan dan persoalan perselisihan penyelenggaraan pemilu sudah ada mekanisme proseduralnya. Namun, MK menyatakan, perselisihan dimaknai bukan hanya sebagai masalah "kuantitas" rekapitulasi hasil suara saja, namun juga menyangkut kualitas pemilu dengan menyatakan secara materiil telah terjadi pelanggaran ketentuan Pilkada yang berpengaruh pada perolehan suara, Mahkamah juga membuat kualifikasi apakah pelanggaran itu bersifat sistematis, terstruktur dan masif. ${ }^{12}$

Secara keseluruhan, putusan perkara di MK telah membebaskan diri dari konstruksi normatif awal yaitu peradilan kesalahan penghitungan suara menjadi peradilan konstitusional penyelenggaraan pemilu, berdasarkan hal itu putusan-putusan perkara mencoba memenuhi prinsip hukum progresif. Yurisprudensi dalam putusan MK memunculkan prinsip-prinsip hukum baru dalam perkara perselisihan hasil Pilkada, yaitu ${ }^{13}$ :

a) Prinsip kebenaran materiil mengatasi kebenaran formil.

b) Prinsip keputusan dalam proses demokrasi dapat dibatalkan pengadilan.

12 Bambang widjojanto, Kajian Putusan MK tentang Pemilu \& Pilkada,(Jakarta:Kemitraan, 2009), hlm. 7

13 Janedjri M Gaffar, Hukum Pemilu dalam Yurisprudensi Mahkamah Konstitusi, (Jakarta: Konstitusi Pres, 2013), hlm. 204 
c) Prinsip perlindungan hak konstitusional warga negara.

d) Prinsip memperhatikan perkembangan masyarakat.

\section{c. Perbandingan Pengaturan Hukum Penyelesaian Perselisihan Hasil Pemilihan Kepala Daerah.}

Perpu No.1 Tahun 2014 yang kemudian disahkan oleh DPR menjadi Undang-Undang Nomor 1 Tahun 2015, didahului dengan keluarnya Putusan Mahkamah Konstitusi No. 97/PUU-XI/2013 tentang pengujian Pasal 236 C Undang-Undang Nomor 12 Tahun 2008 tentang Pemerintahan Daerah dan Pasal 29 ayat (1) huruf $e$ Undang-Undang Nomor 48 Tahun 2009 tentang Kekuasaan Kehakiman terhadap UUD NRI Tahun 1945.

Undang-Undang Nomor 1 Tahun 2015 mengatur mengenai pemilihan kepala daerah secara langsung yang diadakan serentak di seluruh Indonesia, sekaligus didalamnya termasuk juga pengaturan perselisihan hasil pemilihan dilakukan oleh Pengadilan Tinggi dan pengajuan keberatan ke MA. Keberlakuan Undang-Undang Nomor 1 Tahun 2015 ternyata tidak berlangsung lama, tidak perlu menunggu pengundangan, DPR kembali merevisi UU tersebut dengan membentuk Undang-Undang Nomor 8 Tahun 2015. Kini, perkara perselisihan hasil pemilihan diperiksa dan diadili oleh badan peradilan khusus, selama badan tersebut belum terbentuk maka penanganan perkara perselisihan hasil pemilihan dilakukan oleh MK.

Penanganan perselisihan hasil pemilihan kepala daerah yang terbaru ini secara jelas memberikan perbedaan dibandingkan dengan pengaturan mengenai pemilihan kepala daerah sebelumnya baik ketika berdasarkan UndangUndang Nomor 32 Tahun 2004 ataupun berdasarkan Undang-Undang Nomor 12 Tahun 2008. Perbandingan pengaturan diantara UU tersebut, dapat dilihat dalam tabel:

\begin{tabular}{|c|c|c|c|c|}
\hline Dasar Hukum & UU No.32 Tahun 2004 & UU No.12 Tahun 2008, & UU No.1 Tahun 2015 & UU No.8 Tahun 2015 \\
\hline $\begin{array}{l}\text { Lembaga } \\
\text { Berwenang }\end{array}$ & $\begin{array}{l}\text { Pengadilan Tinggi } \\
\text { (perselisihan tk Kab/ } \\
\text { Kota) atau Mahkamah } \\
\text { Agung (perselisihan tk } \\
\text { Prov) }\end{array}$ & $\begin{array}{l}\text { Mahkamah Konstitusi } \\
\text { (sebagai peradilan di } \\
\text { tingkat pertama dan } \\
\text { terakhir) }\end{array}$ & $\begin{array}{l}\text { Pengadilan Tinggi, } \\
\text { Pengajuan keberatan } \\
\text { atas Putusan } \\
\text { Pengadilan Tinggi } \\
\text { kepada MA }\end{array}$ & $\begin{array}{l}\text { Badan peradilan } \\
\text { khusus, sebelum badan } \\
\text { peradilan khusus } \\
\text { terbentuk kewenangan } \\
\text { dilakukan oleh MK. }\end{array}$ \\
\hline $\begin{array}{l}\text { Subyek } \\
\text { Perselisihan }\end{array}$ & $\begin{array}{l}\text { Peserta Pemilihan } \\
\text { dengan KPU Prov/Kab/ } \\
\text { Kota }\end{array}$ & $\begin{array}{l}\text { Peserta Pemilihan } \\
\text { dengan KPU Prov/Kab/ } \\
\text { Kota }\end{array}$ & $\begin{array}{l}\text { Peserta Pemilihan } \\
\text { dengan KPU Prov/Kab/ } \\
\text { Kota }\end{array}$ & $\begin{array}{l}\text { Peserta Pemilihan } \\
\text { dengan KPU Prov/Kab/ } \\
\text { Kota }\end{array}$ \\
\hline $\begin{array}{l}\text { Obyek } \\
\text { Perselisihan }\end{array}$ & $\begin{array}{l}\text { Hasil penghitungan suara } \\
\text { yang mempengaruhi } \\
\text { terpilihnya pasangan } \\
\text { calon }\end{array}$ & $\begin{array}{l}\text { hasil penghitungan } \\
\text { suara yang ditetapkan } \\
\text { oleh Termohon (KPUD) } \\
\text { yang mempengaruhi: } \\
\text { a. penentuan Pasangan } \\
\text { Calon yang dapat } \\
\text { mengikuti putaran } \\
\text { kedua Pilkada; atau } \\
\text { b. terpilihnya Pasangan } \\
\text { Calon sebagai kepala } \\
\text { daerah dan wakil } \\
\text { kepala daerah. }\end{array}$ & $\begin{array}{l}\text { penetapan } \\
\text { perolehan suara } \\
\text { yang signifikan dan } \\
\text { dapat mempengaruhi } \\
\text { penetapan calon } \\
\text { untuk maju ke putaran } \\
\text { berikutnya atau } \\
\text { penetapan calon } \\
\text { terpilih } \\
\text { ket: hanya perolehan } \\
\text { suara dengan selisih } \\
\text { jumlah suara tertentu } \\
\text { yang dapat menjadi } \\
\text { objek perselisihan. }\end{array}$ & $\begin{array}{l}\text { penetapan } \\
\text { perolehan suara } \\
\text { yang signifikan dan } \\
\text { dapat mempengaruhi } \\
\text { penetapan calon } \\
\text { untuk maju ke putaran } \\
\text { berikutnya atau } \\
\text { penetapan calon terpilih } \\
\text { ket: hanya perolehan } \\
\text { suara dengan selisih } \\
\text { jumlah suara tertentu } \\
\text { yang dapat menjadi } \\
\text { objek perselisihan. }\end{array}$ \\
\hline
\end{tabular}




\begin{tabular}{|c|c|c|c|c|}
\hline $\begin{array}{l}\text { Batas Waktu } \\
\text { Permohonan }\end{array}$ & $\begin{array}{l}3 \text { hari setelah penetapan } \\
\text { hasil pemilihan kepala } \\
\text { daerah dan wakil kepala } \\
\text { daerah oleh KPUD }\end{array}$ & $\begin{array}{l}3 \text { hari kerja setelah } \\
\text { penetapan hasil } \\
\text { pemilihan kepala } \\
\text { daerah dan wakil } \\
\text { kepala daerah oleh } \\
\text { KPUD }\end{array}$ & $\begin{array}{l}3 \times 24 \text { jam sejak } \\
\text { diumumkan penetapan } \\
\text { perolehan suara oleh } \\
\text { KPUD }\end{array}$ & $\begin{array}{l}3 \times 24 \text { jam sejak } \\
\text { diumumkan penetapan } \\
\text { perolehan suara oleh } \\
\text { KPUD }\end{array}$ \\
\hline $\begin{array}{l}\text { Batas Waktu } \\
\text { Persidangan }\end{array}$ & $\begin{array}{l}14 \text { hari sejak diterimanya } \\
\text { permohonan }\end{array}$ & $\begin{array}{l}14 \text { hari kerja sejak } \\
\text { permohonan dicatat } \\
\text { dalam Buku Registrasi } \\
\text { Perkara Konstitusi }\end{array}$ & $\begin{array}{l}14 \text { hari sejak diterima } \\
\text { permohonan baik } \\
\text { di Pengadilan tinggi } \\
\text { ataupun di MA }\end{array}$ & $\begin{array}{l}45 \text { hari sejak } \\
\text { diterimanya } \\
\text { permohonan }\end{array}$ \\
\hline $\begin{array}{l}\text { Batas Waktu } \\
\text { Pengajuan } \\
\text { Keberatan }\end{array}$ & $\begin{array}{l}\text {-tidak ada- } \\
\text { (Putusan Pengadilan } \\
\text { Tinggi atau Mahkamah } \\
\text { Agung bersifat final dan } \\
\text { mengikat)* }\end{array}$ & $\begin{array}{l}\text {-tidak ada- } \\
\text { (Putusan MK adalah } \\
\text { peradilan tingkat } \\
\text { pertama dan terakhir } \\
\text { yang putusannya } \\
\text { bersifat final dan } \\
\text { mengikat) }\end{array}$ & $\begin{array}{l}3 \text { hari sejak putusan } \\
\text { Pengadilan Tinggi dapat } \\
\text { mengajukan keberatan } \\
\text { ke Mahkamah Agung }\end{array}$ & $\begin{array}{l}\text {-tidak ada- } \\
\text { (Putusan MK adalah } \\
\text { peradilan tingkat } \\
\text { pertama dan terakhir } \\
\text { yang putusannya } \\
\text { bersifat final dan } \\
\text { mengikat) }\end{array}$ \\
\hline
\end{tabular}

* dalam beberapa kasus, Putusan Pengadilan Tinggi atau Mahkamah Agung dapat dilakukan Peninjauan Kembali (PK)

Perubahan Undang-Undang ini selayaknya harus mengikuti perkembangan hukum ketatanegaraan saat ini serta berusaha untuk memperbaiki penyelesaian perselisihan hasil pemilihan kepala daerah berdasarkan pada evaluasi satu dasawarsa penanganan perselisihan sejak pertama kali ditangani oleh MA pada tahun 2005.

Beberapa perbedaan pengaturan terkait perselisihan hasil pemilihan kepala daerah berdasarkan perbandingan Undang-Undang tersebut, antara lain:

1. Adanya pembatasan objek perkara perselisihan pemilihan yaitu penetapan perolehan suara yang signifikan dan dapat mempengaruhi penetapan calon untuk maju ke putaran berikutnya atau penetapan calon terpilih, makna "signifikan" tersebut kemudian diterjemahkan dengan pengertian hanya perolehan suara dengan selisih jumlah suara tertentu saja yang dapat menjadi objek perselisihan. Rentang selisih suara yang dapat diperselisihkan dari $0.5 \%$ $2 \%$.
2. Lembaga yang berwenang untuk mengadili dan memutus perselisihan hasil pemilihan kepala daerah, berdasarkan UndangUndang Nomor 1 Tahun 2015 ditangani oleh Pengadilan Tinggi dan MA sedangkan berdasarkan Undang-Undang perubahannya ditangani oleh badan peradilan khusus, sebelum terbentuknya badan tersebut perselisihan ditangani oleh MK.

3. Di dalam Undang-Undang Nomor 8 Tahun 2015, batas waktu persidangan perselisihan hasil pemilihan kepala daerah di MK menjadi 45 hari sedangkan di Undang-Undang sebelumnya persidangan paling lama 14 hari.

Dengan adanya pengaturan yang baru ini tentu akan memberikan warna yang baru terhadap karakteristik/model penyelesaian perselisihan hasil pemilihan kepala daerah dibandingkan dengan model penyelesaian ketika di MA berdasar Undang-Undang Nomor 32 Tahun 2004 ataupun model penyelesaian ketika di MK berdasar Undang-Undang Nomor 12 Tahun 2008. 


\section{Optimalisasi Penyelesaian Perselisihan Hasil Pemilihan Kepala Daerah}

Lembaga yang berwenang untuk menangani perselisihan hasil pemilihan masih menimbulkan banyak perdebatan, dengan saling berpindahnya kewenangan lembaga yang berhak menangani perselisihan hasil pemilihan menjadi pertanyaan besar kemanakah arah kebijakan penanganan sengketa hasil pemilihan ini?, apakah di MK atau MA ataukah badan peradilan khusus?

Pasca putusan MK yang berisi bahwa MK tidak berwenang menangani perselisihan hasil pemilihan kepala daerah maka lembaga yang memungkinkan untuk menangani perselisihan hasil pemilihan adalah Pengadilan Tinggi atau MA seperti tercantum dalam UndangUndang Nomor 1 Tahun 2015 atau dibentuk badan peradilan khusus yang menangani penyelesaian perselisihan pemilihan kepala daerah sebagaimana yang tercantum dalam UU perubahannya.

Menurut hemat penulis, optimalisasi Pengadilan Tinggi atau MA untuk menangani perselisihan lebih tepat dibandingkan pembentukan badan peradilan khusus pemilihan kepala daerah. hal yang perlu dipertimbangkan antara lain:

a. pemilihan kepala daerah selanjutnya akan dilakukan secara serentak lima tahun sekali. Tidak efisien untuk membentuk suatu badan peradilan baru, dimana badan tersebut hanya bekerja lima tahun sekali. Hal ini berbeda dengan pengadilan khusus seperti pengadilan pajak atau pengadilan hubungan industrial yang memiliki perkara rutin yang harus ditangani.

Pelaksanaan pemilihan secara serentak juga menjadi alasan bahwa MA tidak perlu khawatir sengketa pemilihan kepala daerah akan semakin menambah banyak tumpukan perkara di MA. Perkara perselisihan hasil pemilihan hanya akan ditangani dalam masa tertentu ( 5 tahunan), objek perkara tertentu (rentang selisih suara 0,5\%-2\%) dan dengan batas waktu persidangan yang juga sudah ditentukan ( dalam Undang-Undang Nomor 1 Tahun 2015 ditentukan paling lama 14 hari), oleh karena itu, perkara perselisihan pemilihan dirasa tidak akan signifikan menyita waktu persidangan.

b. MA dan Pengadilan Tinggi telah memiliki SDM dan infrastuktur pengadilan yang siap untuk digunakan. SDM hakim dan infrastuktur pengadilan tersebut masih dapat digunakan untuk menangani sengketa lain apabila masa penanganan perselisihan hasil pemilihan telah selesai dilakukan, hal ini lebih efisien dibanding dengan adanya pembentukan badan peradilan baru yang tentu perlu pula ada penyiapan infrastruktur dan SDM baru untuk badan peradilan tersebut. Selama ini penanganan sengketa administrasi antara calon dan KPU ditangani oleh Pengadilan TUN, sedangkan perkara pidana ditangani di pengadilan umum, dengan demikian sesungguhnya hakim di lingkungan peradilan di MA telah familiar dengan jenis perselisihan terkait pemilihan kepala daerah.

c. perselisihan pemilihan kepala daerah banyak jenisnya dapat berupa pelanggaran etik, administrasi, tindak pidana ataupun tata usaha negara, terlalu kompleks untuk menempatkan berbagai jenis perselisihan tersebut ke dalam satu badan peradilan tersendiri. Hal ini juga mempertimbangkan konsistensi prinsip satu atap kekuasaan kehakiman dibawah MA. 
Penanganan perselisihan hasil pemilihan kepala daerah sesungguhnya layak untuk dilakukan oleh MA namun tentu dengan berbagai optimalisasi perbaikan sebagaimana refleksi satu dasawarsa penanganan perselisihan hasil pemilihan antara lain pendekatan mekanisme penanganan perkara, penyiapan materi SDM hakim serta perbaikan lembaga-lembaga lain yang terkait dengan penanganan perselisihan pemilihan kepala daerah.

\section{a. Optimalisasi Perbaikan Mekanisme Penanganan Perselisihan Hasil Pemilihan}

Selama satu dasawarsa penanganan perselisihan hasil pemilihan kepala daerah baik ditangani oleh MA ataupun MK, masing-masing memiliki karakteristik tersendiri, penanganan di MA lebih mengedepankan pada prinsip keadilan prosedural (procedural justice) sedangkan di MK lebih mengutamakan keadilan substantive (substantive justice). Karakteristik dari peradilan procedural dan peradilan substantive memiliki perbedaan $^{14}$

Pendekatan yang dilakukan oleh MA akan lebih terlihat kepastian hukumnya mengingat penanganan yang dilakukan sesuai dengan peraturan perundang-undangan dan dapat terhindar dari pergulatan substansi yang bisa menarik keluar konteks penanganan perselisihan dari yang seharusnya. Namun begitu, melalui mekanisme ini peserta pemilihan tidak bisa berharap banyak untuk dapat menggali keadilan selama penyelenggaraan pemilu, karena penanganan di MA sesuai kewenangannya terbatas pada rekapitulasi hasil suara.
Pendekatan yang dilakukan oleh MK dengan hukum progresifnya akan lebih memuaskan rasa keadilan dari pemohon karena prinsip bahwa tidak ada satupun pasangan calon yang boleh diuntungkanataupun dirugikan dalamperolehan hasil suara akibat terjadinya pelanggaran selama tahap penyelenggaraan pemilihan dapat benarbenar diterapkan, walaupun kemudian ada pula yang merespon negative pendekatan ini karena MK dinilai telah menyimpang dari undangundang serta putusan yang dikeluarkan tidak jarang pula meninggalkan perdebatan substansi di luar pengadilan.

Berdasarkan penilaian satu dasawarsa penanganan penyelesaian perselisihan hasil pemilu, penulis menilai positif pendekatan MK sewaktu menangani permasalahan Pilkada. Walaupun ada pandangan bahwa MK telah keluar dari koridor hukum yang seharusnya, namun demikian terobosan hukum tersebut harus dilakukan agar MK dalam kerangka hukum progresifnya tidak hanya mengadili dari sisi aspek rigiditas hukum saja tetapi lebih dari itu melampaui hukum dalam rangka mencari keadilan yang sebenar-benarnya.

Penulis menilai bahwa pendekatan yang selama ini telah dilakukan oleh MK dengan mengutamakan keadilan substantive (substantive justice) perlu untuk dilakukan kembali dalam menangani perselisihan hasil pemilihan di masa mendatang. Perselisihan hasil pemilihan kepala daerah pada dasarnya tidak hanya sebatas perselisihan perdata dari pihak yang terlibat, namun lebih dari itu menyangkut pula kepentingan masyarakat luas dan juga dalam rangka menjaga nilai-nilai demokrasi yang jujur dan adil.

4 Faisal, Menerobos Positivisme Hukum, (Jakarta: Gramata Publishing, 2012), hal 69. 
Gustav Radbruch menuturkan bahwa hukum adalah pengemban nilai keadilan, keadilan memiliki sifat normatif sekaligus konstitutif bagi hukum. Bersifat normative karena kepada keadilanlah, hukum positif berpangkal. Bersifat konstitutif karena keadilan harus menjadi unsur mutlak bagi hukum, tanpa keadilan, sebuah aturan tidak pantas menjadi hukum ${ }^{15}$. Hal ini memperhatikan pula asas prioritas yang dikemukakan oleh Gustav Radbruch bahwa untuk menerapkan hukum secara tepat dan adil untuk memenuhi tujuan hukum maka yang diutamakan adalah keadilan, kemudian kemanfaatan setelah itu kepastian hukum ${ }^{16}$.

Berdasarkan pemaparan tersebut, layak dipertimbangkan bahwa pendekatan yang dilakukan lembaga penanganan perselisihan hasil pemilihan masa depan adalah pendekatan substantive. Optimalisasi penanganan sengketa pemilihan oleh KPU, Bawaslu ataupun lembaga lainnya di tahap awal tidak menjadikan Pengadilan perselisihan hasil pemilihan hanya sebagai pengadilan penghitungan, dalam hal lembaga hukum di tahap sebelumnya tidak bekerja sebagaimana mestinya, sensitivitas keadilan tersebut harus dijaga oleh MA.

Undang-Undang Nomor 1 Tahun 2015 memberikan penguatan berupa pengaturan dibentuknya Majelis Khusus di Pengadilan Negeri dan Pengadilan Tinggi untuk penanganan tindak pidana, Majelis Khusus di Pengadilan TUN untuk perselisihan tata usaha negara serta hakim yang menangani perselisihan hasil pemilihan. Pengaturan ini masih dipertahankan dalam UU perubahannya.
Langkah ini harus diperkuat kembali dengan memastikan bahwa hakim-hakim yang ada di dalam Majelis Khusus tersebut adalah hakim yang memiliki integritas berdasarkan rekam jejaknya, mengingat perkara pemilu sangat sarat kepentingan politik dan ekonomi. Selain itu, hakim tersebut harus pula memiliki pengetahuan yang luas seputar hukum pemilihan kepala daerah dan yang terpenting adalah memiliki karakter untuk mampu menggali keadilan sedalam-dalamnya untuk menjaga nilai-nilai demokrasi yang terkandung dalam penyelenggaraan pemilihan kepala daerah.

Pengadilan yang merdeka, netral, kompeten dan berwibawa yang mampu menegakkan wibawa hukum, pengayoman hukum, kepastian hukum dan keadilan merupakan condition sine qua non negara yang berdasarkan hukum. ${ }^{17}$ Pengadilan sebagai rumah keadilan pelaksanaannya diwakili oleh hakim, oleh karena itu, kepercayaan masyarakat terhadap hukum dan institusi peradilan sangat ditentukan oleh kredibilitas dan profesionalitas hakim dalam menjalankan tugasnya menyelesaikan perselisihan serta menegakkan keadilan ${ }^{18}$. Berdasarkan hal ini pula selain hakim karier dapat dipertimbangkan merekruit ahli lain sebagai hakim non karier.

Tantangan selanjutnya adalah membuat hukum acara yang memungkinkan keadilan dapat diperjuangkan sekaligus menjamin kepastian hukum. Dibutuhkan pelaksanaan persidangan yang cepat,terbuka dan putusan yang final dan mengikat dalam penyelesaian

\footnotetext{
15 Bernard L Tanya dkk, Teori Hukum: Strategi Tertib Manusia Lintas Ruang dan Generasi, (Yogyakarta, Genta Publising, 2013), hal 117

16 Satjipto rahardo, ilmu hukum, (Bandung, Citra Aditya Bakti, 2000), hal 20.

17 Ali Taher Parasong, Mencegah Runtuhnya Negara Hukum,(Jakarta:Grafindo,2014), hal 223

18 Didik Sukriono, Hukum, Konstitusi dan Konsep Otonomi, (Malang: Setara Press, 2013), hal 104
} 
perselisihan hasil pemilihan kepala daerah sehingga tidak menyebabkan kekosongan pemerintahan di daerah.

Demokrasi yang diharapkan adalah demokrasi electoral sekaligus demokrasi substantive, jika realisasi demokrasi electoral diukur hanya sebatas pemilu yang bebas, kompetitif dan demokratis, maka realisasi demokrasi substantive mensyaratkan lebih dari sekedar penyelanggaraan pemilu. Demokrasi substantive mencakup aspek yang lebih luas meliputi kebebasan sipil dan politik, jaminan HAM hingga terwujudnya good governance ${ }^{19}$.

\section{b. Optimalisasi Perbaikan Lembaga Penanganan Perselisihan Pemilihan.}

Berdasarkan kasus-kasus perselisihan hasil pemilihan kepala daerah yang masuk ke MA ataupun MK selama satu dasawarsa terakhir, para calon kepala daerah banyak yang memasukkan pelanggaran-pelanggaran administrasi, tindak pidana pemilu dan perselisihan dalam tahapan pemilihan sebagai dasar gugatan untuk di MA ataupun MK, padahal kasus - kasus tersebut bukan kewenangan MA atau MK untuk memutusnya, terkait dengan hal ini, menurut Hakim MK, Hamdan Zoelva, ada tiga kemungkinan kenapa hal tersebut dapat terjadi, yaitu ${ }^{20}$ :

1. peserta pemilihan masih tidak puas dengan penyelenggaraan Pemilihan baik dalam prosesnya maupun dalam hasil akhirnya.

2. Ketidakpercayaan dan pengabaian peserta pemilihan terhadap instansi lembaga hukum atau pengawas pemilihan.

3. ketidakpahaman dasar gugatan yang diajukan para peserta pemilihan.

Saat ini telah ada Lembaga-lembaga yang terkait dengan penyelesaian perselisihan hukum semacam itu seperti dalam tabel berikut:
Model pelanggaran/perselisihan

Pelanggaran Kode Etik Pemilu

Pelanggaran Administrasi

Perselisihan pemilihan

Tindak Pidana Pemilihan

\section{Lembaga yang berwenang}

Diperiksa dan diputus oleh Dewan Kehormatan Penyelenggara Pemilu (DKPP)

Diperiksa oleh Bawaslu untuk kemudian penanganannya diselesaikan oleh KPU Prov/Kab/Kota

Diperiksa dan diputus oleh Bawaslu Prov dan Panwaslu Kab/Kota

Disidik oleh Kepolisian kemudian penyelesaiannya diteruskan kepada

Pengadilan Negeri untuk diperiksa, diadili, dan diputus perkaranya.

Putusan Pengadilan Negeri dapat diajukan banding ke Pengadilan Tinggi.

Perselisihan Tata Usaha Negara Penanganan melalui upaya administrative di Bawaslu Prov dan/atau (TUN) Panwas.

Dalam hal perselisihan TUN belum putus, Pengajuan gugatan atas perselisihan TUN dilakukan ke Pengadilan Tinggi TUN.

Perselisihan Hasil Pemilihan Mahkamah Konstitusi 
Pengalaman penanganan perselisihan hasil pemilihan kepala daerah, hampir selalu tidak terlepas dari pelanggaran-pelanggaran yang terjadi di hulunya yaitu pada tahap penyelenggaraan pemilihan, oleh karena itu optimalisasi lembaga pemutus perselisihan hasil pemilihan kepala daerah harus disertai pula dengan perbaikan kinerja lembaga - lembaga lainnya yang memutus perselisihan pada tahap awal proses penyelenggaran pemilihan. Apabila peserta pemilu sudah mendapatkan keadilan dari lembaga - lembaga hukum penyelenggara pemilu maka tentu semuanya tidak akan menggantungkan nasibnya pada lembaga yudikatif seperti MA atau MK. Lembaga hukum pemilihan kepala daerah yang dimaksud antara lain ${ }^{21}$ :

1. Komisi Pemilihan Umum Daerah selaku penyelenggara Pilkada yang mempunyai wewenang memberikan sanksi terhadap para pelaku pelanggaran administrasi pemilu,

2. Bawaslu Prov atau Panwas Kab/Kota selaku pengawas yang diberi wewenang untuk memastikan ada-tidaknya pelanggaran pemilu dan menyelesaikaan perselisihan non-hasil Pilkada,

3. jajaran kepolisian dan kejaksaan,

4. lembaga peradilan yang berwenang menyidangkan dan menjatuhkan vonis terhadap pelaku penyelenggaran Pilkada.

Terkait dengan penanganan tindak pidana, Pasal 150 Perpu No.1 Tahun 2014 menyatakan bahwa "putusan pengadilan yang menurut Undang-Undang dapat mempengaruhi perolehan suara peserta pemilihan harus sudah selesai paling lama 5 (lima) hari sebelum KPU Prov/Kab/Kota menetapkan hasil pemilihan", selanjutnya "KPU Prov/Kab/Kota wajib menindaklanjuti putusan pengadilan terkait tindak pidana tersebut", frase ini seharusnya dimanfaatkan semaksimal mungkin bagi para peserta pemilihan, sehingga kasus-kasus tindak pidana tidak perlu lagi diperkarakan di pengadilan perselisihan hasil pemilihan kepala daerah.

\section{Penutup}

Undang-Undang Nomor 1 Tahun 2015 telah mengamanahkan MA sebagai lembaga yang berwenang mengadili dan memutus perselisihan hasil pemilihan, namun tak berlangsung lama, Undang-Undang tersebut direvisi dengan memberikan kewenangan mengadili dan memutus perselisihan hasil pemilihan kepada badan peradilan khusus, sebelum terbentuknya badan peradilan tersebut, kewenangan dilakukan oleh MK. Saling limpah-melimpahkan kewenangan ini sesungguhnya telah memberikan keraguan tentang kemanakah arah penanganan perselisihan hasil pemilihan kepala daerah di masa mendatang.

Pembelajaran hukum selama satu dasawarsa terakhir penanganan perselisihan hasil pemilihan harus didalami untuk memperoleh model penyelesaian perselisihan hasil pemilihan kepala daerah yang lebih baik lagi. Dalam hal MK tidak berwenang menangani perselisihan maka MA atau Pengadilan Tinggi sesungguhnya masih layak untuk dijadikan lembaga yang berwenang menangani perselisihan tersebut dibanding badan peradilan khusus, walaupun tentu dengan berbagai perbaikan berdasarkan refleksi satu dasawarsa penanganan perselisihan.

Pengalaman pendekatan hukum progresif yang telah dilakukan oleh MK selama beberapa tahun terakhir dinilai lebih menjamin

21 Hamdan Zoelva, ibid. hal 392. 
tercapainya keadilan yang diharapkan oleh para pihak, berdasarkan hal itu, pendekatan penanganan perselisihan hasil pemilihan perlu untuk dikawal. Perlu kebijakan dari MA yang mengarah pada rekrutmen/penempatan hakim-hakim yang berintegritas dan mumpuni dalam menangani perselisihan pemilihan kepala daerah, serta hakim yang mengedepankan keadilan substantive dalam penyelesaian perselisihan hasil. Terkait penunjukan hakim harus dibuka juga kemungkinan untuk hakim non karier baik berasal dari praktisi atau akademisi untuk menempati posisi tersebut.

Pengalaman satu dasawarsa terakhir menunjukan bahwa persidangan perselisihan hasil pemilihan tidak semata-mata menampilkan sengketa hasil saja, namun lebih dari itu banyak pula pelanggaran tindak pidana yang dikeluhkan, oleh karena itu perbaikan tidak cukup hanya pada tahap penanganan perselisihan hasil pemilihan, namun perlu pula ada optimalisasi di tahap-tahap sebelum perselisihan hasil diperkarakan. Optimalisasi penegakan hukum yang dilakukan oleh KPU, Bawaslu/Panwaslu, DKPP ataupun penegak hukum lainnya yang menangani sengketa di tahap awal perlu terus ditingkatkan sehingga tidak menjadikan beban berat pada saat penanganan perselisihan hasil pemilihan.

\section{DAFTAR PUSTAKA}

\section{Buku:}

Akbar, Patrialis, Lembaga-Lembaga Negara Menurut UUD NRI Tahun 1945, (Jakarta: Sinar Grafika, 2013)

Faisal, Menerobos Positivisme Hukum, (Jakarta: Gramata Publishing, 2012)

Gaffar, Janedjri M, Hukum Pemilu dalam Yurisprudensi Mahkamah Konstitusi, (Jakarta: Konstitusi Pres, 2013)

Lotulung,Paulus Effendi, Aspek Yuridis masalah Sengketa Pilkada, (Jakarta:LPPHAN, 2005)
Manan, Munafrizal, Partai Politik dan Demokrasi Indonesia menyongsong Pemilihan Umum 2014, (Jurnal Legislasi Indonesia, vol. 9 No. 4, Desember 2012)

Parasong, Ali Taher, Mencegah Runtuhnya Negara Hukum,(Jakarta:Grafindo,2014)

Rahardjo, Satjipto, Ilmu Hukum, (Bandung: Citra Aditya Bakti, 2000)

Soekanto, Soejono, Pengantar Penelitian Hukum, (Jakarta: UI Press, 2010)

Sukriono, Didik, Hukum, Konstitusi dan Konsep Otonomi, (Malang: Setara Press, 2013)

Tanya, Bernard L, dkk, Teori Hukum: Strategi Tertib Manusia Lintas Ruang dan Generasi, (Yogyakarta: Genta Publising, 2013)

Widjojanto, Bambang, Kajian Putusan MK tentang Pemilu \& Pilkada, (Jakarta: Kemitraan, 2009)

Zoelva, Hamdan, Problematika Penyelesaian Sengketa Hasil Pilkada oleh Mahkamah Konstitusi, (Jurnal Konstitusi volume 10, nomor 3, September 2013)

\section{Peraturan Perundang-undangan}

Undang-Undang No. 32 Tahun 2004 tentang Pemerintahan Daerah.

Undang-Undang No. 22 Tahun 2007 tentang Penyelenggaraan Pemilihan Umum.

Undang-Undang No. 12 Tahun 2008 tentang Perubahan atas UU No. 32 Tahun 2004 tentang Pemerintahan Daerah.

Undang-Undang No.1 Tahun 2015 tentang Penetapan Perppu No.1 Tahun 2014 tentang Pemilihan Gubernur, Bupati dan Walikota menjadi UU.

Perma No. 2 Tahun 2005 tentang Tata Cara Pengajuan Upaya Hukum Keberatan Penetapan Hasil Pilkada dan Pilwakada KPUD Provinsi dan KPUD Kab/Kota.

PMK No. 15 Tahun 2008 tentang Pedoman Beracara Dalam Perselisihan Hasil Pemilihan Umum Kepala Daerah

\section{Putusan Pengadilan}

Putusan Pengadilan Tinggi Jawa Barat No.01/ PILKADA/2005/PT.Bdg.

Putusan Mahkamah Agung Nomor 01 PK/ PILKADA/2005.

Putusan Mahkamah Konstitusi No. 41/PHPU.D$\mathrm{VI} / 2008$. 


\title{
INISIASI PENGADILAN KHUSUS PEMILIHAN KEPALA DAERAH DALAM MENGHADAPI KESERENTAKAN PEMILIHAN GUBERNUR, BUPATI, DAN WALIKOTA DI INDONESIA ${ }^{1 *}$
}

\author{
(Initiation of Special Court on the Local Election for Regional Leaders \\ to Face the Simultaneously Election of Governor, Regent, and Mayor in Indonesia)
}

\author{
Dian Agung Wicaksono \\ Bagian Hukum Tata Negara Fakultas Hukum Universitas Gadjah Mada \\ Jl. Sosio Yustisia No. 1 Bulaksumur, Sleman, D.I. Yogyakarta \\ Email: dianagung@ugm.ac.id \\ Ola Anisa Ayutama \\ Program Studi Ilmu Hukum Fakultas Hukum Universitas Gadjah Mada \\ JI. Sosio Yustisia No. 1 Bulaksumur, Sleman, D.I. Yogyakarta \\ Email: ola.anisa@ymail.com
}

Naskah diterima: 5 Februari 2015; revisi: 24 April 2015; disetujui: 30 April 2015

\begin{abstract}
Abstrak
Pasca pengesahan Peraturan Pemerintah Pengganti Undang-Undang (selanjutnya disingkat Perppu) Nomor 1 Tahun 2014 tentang Pemilihan Gubernur, Bupati, dan Walikota (selanjutnya disebut Pemilihan Kepala Daerah, yang disingkat Pilkada) terdapat desain baru yang diusung terkait mekanisme Pilkada. Dalam Perppu tersebut, Pilkada diselenggarakan secara serentak pada level nasional. Desain keserentakan ini tentu membutuhkan regulasi pendukung, salah satunya melalui pembentukan pengadilan khusus Pilkada. Permasalahan yang kemudian muncul dalam penelitian ini adalah terkait bagaimana urgensi dibentuknya pengadilan khusus Pilkada, bagaimana perbandingan pengadilan khusus Pilkada di berbagai negara dan bagaimana relevansi perbandingan tersebut dapat diterapkan di Indonesia. Penelitian ini dilakukan dengan metode yuridis normatif. Kesimpulan dari penelitian ini adalah terdapat urgensi untuk dibentuk pengadilan khusus Pilkada dikarenakan upaya hukum dalam proses Pilkada selama ini seringkali tidak dapat memenuhi rasa keadilan masyarakat, misalnya putusan pengadilan yang baru diputus pasca tahapan Pilkada telah dilaksanakan dan berlapislapisnya upaya hukum Pilkada sehingga kontraproduktif dengan tahapan Pilkada yang dibatasi jangka waktu. Terlebih upaya hukum tersebut terpisah dalam beberapa lingkungan peradilan. Di berbagai negara pun telah dibentuk pengadilan khusus Pilkada dengan berbagai desain kelembagaan dan hukum acaranya. Untuk Indonesia, Pengadilan Pilkada didesain sebagai pengadilan khusus yang bersifat ad hoc, berkedudukan di Provinsi dan Kabupaten atau Kota serta berwenang memutus sengketa tentang Pilkada.
\end{abstract}

Kata Kunci: pengadilan khusus, pemilihan kepala daerah, pemilihan serentak.

\begin{abstract}
Post-approval of Government Regulation in Lieu of Law No. 1 of 2014 concerning the Election of Governor, Regent, and Mayor (hereinafter called local election), there is a new design in election mechanisms of regional head. The Law a quo stated that the elections be held simultaneously at the national level. This design would require regulatory support, such as the establishment of special courts to solve any disputes that arise from the election. The problems emerge in this study is how the urgency of a special court, how it compares to special court on election matters in various countries and how the relevance of the comparison can be applied in Indonesia. This was conducted using a legal-normative research. The research conclude that it is urgent to set up special courts on local elections due to legal remedy in the local election process that has been often unable to meet the demands for justice, for example, the court's decision are settled after the elections conducted and thick-layers on legal remedies so it is counterproductive to the elections that have limited period of time. These legal remedies are even separated in several judicatures. Various countries have also established a special court on local elections with a variety of institutional design and procedural law. For Indonesia, the special court is an ad hoc court, based on provincial and district or city and authorized to settle disputes concerning the local elections.
\end{abstract}

Keywords: special court, local election for regional leaders, simultaneous election

1 Versi sebelumnya dari tulisan ini disajikan pada Seminar Pengkajian Hukum Nasional (SPHN 2014) "Prospek Pembaruan Hukum Pemerintahan Joko Widodo dan Muhammad Jusuf Kalla Periode Tahun 2014-2019”, Hotel Bidakara, Jakarta, 2-3 Desember 2014. 


\section{A. Pendahuluan}

Indonesia termasuk salah satu negara yang meneguhkan diri sebagai negara demokratis. Konsep demokrasi yang dipilih oleh Indonesia adalah demokrasi konstitusional sebagaimana bunyi rumusan Pasal 1 ayat (2) Undang-Undang Dasar Negara Republik Indonesia Tahun 1945 (UUD NRI Tahun 1945) yang menegaskan bahwa, "Kedaulatan berada di tangan rakyat dan dilaksanakan menurut Undang-Undang Dasar 1945"2. Salah satu bentuk perwujudan instrumen demokrasi tersebut adalah melalui pemilihan kepala daerah (Pilkada). Instrumentasi demokrasi di daerah berupa Pilkada tidak dapat dilepaskan dari konsep pelimpahan pelaksanaan urusan pemerintahan kepada daerah (decentralisation), namun pula devolusi kekuasaan (political decentralization). ${ }^{3}$ Pemilihan ini merupakan momentum bagi masyarakat daerah untuk menyalurkan otonominya dalam menentukan siapa yang akan memimpin pembangunan di daerahnya, sehingga dengan adanya hal tersebut pembangunan kesejahteraan daerah akan lebih berbasis pada kepentingan masyarakat. Mengingat pentingnya peran Pilkada, maka dalam Pasal 18 ayat (4) UUD NRI Tahun 1945 telah ditegaskan bahwa "Gubernur, Bupati, dan Walikota masing-masing sebagai kepala pemerintah daerah provinsi, kabupaten, dan kota dipilih secara demokratis." ${ }^{4}$ Selanjutnya, Pasal 18 ayat (7) UUD NRI Tahun 1945 menyatakan bahwa "Susunan dan tata cara penyelenggaraan pemerintahan daerah diatur dalam undangundang" ${ }^{5}$, yang maknanya pengaturan Pilkada sebagai salah satu bentuk penyelenggaraan pemerintahan daerah diserahkan pada tataran Undang-Undang.

Di Indonesia, pengaturan mengenai Pilkada selama ini masuk sebagai substansi UndangUndang Pemerintahan Daerah, mulai dari Undang-Undang Nomor 22 Tahun 1999 tentang Pemerintahan Daerah, yang selanjutnya dicabut dengan Undang-Undang Nomor 32 Tahun 2004 dan perubahannya, yaitu Undang-Undang Nomor 12 Tahun 2008. Namun demikian, Dewan Perwakilan Rakyat (DPR) dan Pemerintah telah membuat kesepakatan bersama untuk tidak lagi memasukkan Pilkada sebagai substansi Undang-Undang Pemerintahan Daerah, yang tindak lanjutnya dengan memecah UndangUndang Pemerintahan Daerah ke dalam 3 (tiga) Undang-Undang, yaitu Undang-Undang tentang Pemerintahan Daerah, Undang-Undang tentang Desa dan Undang-Undang tentang Pilkada. Diharapkan melalui pemecahan Undang-Undang Pemerintahan Daerah ke dalam tiga Undang-Undang tersebut akan memberikan ruang pengaturan yang lebih rinci dan komprehensif dari masing-masing isu tersebut sehingga memberikan kontribusi pada kelancaran jalannya roda pemerintahan daerah secara keseluruhan. ${ }^{6}$

Implementasi dari kesepakatan tersebut, terbitlah Undang-Undang Nomor 22 Tahun 2014 tentang Pemilihan Gubernur, Bupati, dan

Pasal 1 ayat (2) Undang-Undang Dasar Negara Republik Indonesia Tahun 1945.

William Tordoff, "Decentralisation: Comparative Experience in Commonwealth Africa", The Journal of Modern African Studies 32:4 (Dec., 1994): 573.

Pasal 18 ayat (4) Undang-Undang Dasar Negara Republik Indonesia Tahun 1945.

Pasal 18 ayat (7) Undang-Undang Dasar Negara Republik Indonesia Tahun 1945.

6 Gamawan Fauzi, "Keterangan Pemerintah Atas Rancangan Undang-Undang tentang Pemerintahan Daerah" (Rapat Kerja Pansus Rancangan Undang-Undang tentang Pemerintahan Daerah, Jakarta, 3 April 2012). 
Walikota yang kemudian dikarenakan polemik mekanisme pemilihan, akhirnya dianulir oleh Presiden dengan penerbitan Peraturan Pemerintah Pengganti Undang-Undang Nomor 1 Tahun 2014 tentang Pemilihan Gubernur, Bupati, dan Walikota (Perppu Pilkada). Permasalahan mendasar yang menjadi diskursus pengaturan adalah terkait mekanisme Pilkada apakah secara langsung atau tidak langsung. Pun pada awalnya menuai perdebatan terkait hal tersebut pada DPR periode tahun 2004-2009, namun pada akhirnya pada tanggal 20 Januari 2015, DPR periode 2009-2014 mengesahkan Perppu Pilkada menjadi Undang-Undang Nomor 1 Tahun 2015 tentang Penetapan Peraturan Pemerintah Pengganti Undang-Undang Nomor 1 Tahun 2014 tentang Pemilihan Gubernur, Bupati, dan Walikota Menjadi Undang-Undang (UU Pilkada), dengan catatan mengusulkan agar dilakukan revisi setelah resmi disahkan menjadi UU. ${ }^{7}$

Menurut UU Pilkada, Pilkada serentak secara nasional akan dilaksanakan pada tahun $2020,{ }^{8}$ namun kemudian dalam perubahan UU Pilkada yang sudah disahkan dalam Rapat Paripurna DPR disepakati bahwa Pilkada serentak dalam beberapa tahap yang dimulai Desember 2015, serta pelaksanaan pemilihan serentak nasional pada tahun 2027. ${ }^{9}$ Berikut adalah beberapa poin materi perubahan UU Pilkada yang disahkan pada tanggal 17 Februari 2015, yaitu: ${ }^{10}$

1. Penguatan pendelegasian tugas kepada KPU dan Bawaslu sebagai penyelenggara pemilihan disertai adanya penguatan bahwa kedua lembaga tersebut secara atributif diberikan tugas oleh UU ini ${ }^{11}$, untuk menegaskan bahwa pemilihan Gubernur, Bupati, dan Walikota adalah rezim pemerintahan daerah sebagaimana Pasal 18 ayat (4) UUD NRI Tahun 1945.

2. Syarat pendidikan Gubernur, Bupati, dan Walikota tetap seperti dalam Perppu Nomor 1 Tahun 2014, yaitu berpendidikan paling rendah SLTA atau sederajat. ${ }^{12}$

3. Syarat usia Gubernur tetap seperti dalam Perppu Nomor 1 Tahun 2014, yaitu berusia

A. Haryo Damardono dan Anita Yossihara, "Paripurna DPR Sahkan Pilkada Langsung" (Kompas, 20 Januari 2015).

8 Pasal 201 ayat (5) Undang-Undang Nomor 1 Tahun 2015 tentang Penetapan Peraturan Pemerintah Pengganti Undang-Undang Nomor 1 Tahun 2014 tentang Pemilihan Gubernur, Bupati, dan Walikota Menjadi UndangUndang (Lembaran Negara Republik Indonesia Tahun 2015 Nomor 23, Tambahan Lembaran Negara Republik Indonesia Nomor 5656).

9 Dewan Perwakilan Rakyat Republik Indonesia, "Paripurna DPR Setujui Revisi UU Pilkada dan RUU Pemda Menjadi UU", http://dpr.go.id/berita/detail/id/9734, (diakses 11 Maret 2015).

10 Diolah oleh Penulis dengan membandingkan antara Undang-Undang Nomor 8 Tahun 2015 tentang Perubahan Atas Undang-Undang Nomor 1 Tahun 2015 tentang Penetapan Peraturan Pemerintah Pengganti Undang-Undang Nomor 1 Tahun 2014 tentang Pemilihan Gubernur, Bupati, dan Walikota Menjadi Undang-Undang (Lembaran Negara Republik Indonesia Tahun 2015 Nomor 57, Tambahan Lembaran Negara Republik Indonesia Nomor 5678) dengan Undang-Undang Nomor 1 Tahun 2015 tentang Penetapan Peraturan Pemerintah Pengganti Undang-Undang Nomor 1 Tahun 2014 tentang Pemilihan Gubernur, Bupati, dan Walikota Menjadi UndangUndang (Lembaran Negara Republik Indonesia Tahun 2015 Nomor 23, Tambahan Lembaran Negara Republik Indonesia Nomor 5656).

11 Penjelasan Undang-Undang Nomor 8 Tahun 2015 tentang Perubahan Atas Undang-Undang Nomor 1 Tahun 2015 tentang Penetapan Peraturan Pemerintah Pengganti Undang-Undang Nomor 1 Tahun 2014 tentang Pemilihan Gubernur, Bupati, dan Walikota Menjadi Undang-Undang (Lembaran Negara Republik Indonesia Tahun 2015 Nomor 57, Tambahan Lembaran Negara Republik Indonesia Nomor 5678).

12 Pasal 7 huruf c Undang-Undang Nomor 8 Tahun 2015 tentang Perubahan Atas Undang-Undang Nomor 1 Tahun 2015 tentang Penetapan Peraturan Pemerintah Pengganti Undang-Undang Nomor 1 Tahun 2014 tentang Pemilihan Gubernur, Bupati, dan Walikota Menjadi Undang-Undang (Lembaran Negara Republik Indonesia Tahun 2015 Nomor 57, Tambahan Lembaran Negara Republik Indonesia Nomor 5678). 
paling rendah 30 tahun dan Bupati/Walikota berusia paling rendah 25 tahun. ${ }^{13}$

4. Tahapan Uji Publik dihapus. ${ }^{14}$ Dengan alasan bahwa proses tersebut menjadi domain atau kewajiban dari partai politik dan termasuk perseorangan yang harus melakukan proses sosialisasi calon. ${ }^{15}$

5. Syarat dukungan penduduk untuk Calon Perseorangan dinaikkan 3,5\%, sehingga nantinya threshold perseorangan antara 6,5\%-10\%. Tergantung daerah dan jumlah penduduknya. ${ }^{16}$

6. Pembiayaan Pilkada dari APBD didukung APBN. ${ }^{17}$

7. Ambang batas kemenangan $0 \%$, artinya satu putaran. ${ }^{18}$ Alasannya untuk efisiensi baik waktu maupun anggaran. Selain itu, dengan syarat dukungan baik dari partai politik atau gabungan partai politik dan calon perseorangan yang sudah dinaikkan maka sesungguhnya para calon sudah memiliki dasar legitimasi yang cukup. Proses pemilihan menjadi lebih sederhana.

8. Tentang sengketa hasil Pilkada disepakati bahwa sebelum terbentuknya lembaga peradilan khusus yang menangani, maka proses penyelesaiannya dilakukan oleh Mahkamah Konstitusi. ${ }^{19}$

9. Jadwal Pilkada dilaksanakan dalam beberapa gelombang sebagai berikut:
a. Gelombang pertama dilaksanakan Desember 2015 (untuk akhir masa jabatan 2015 dan semester pertama tahun 2016). ${ }^{20}$

13 Pasal 7 huruf e Undang-Undang Nomor 8 Tahun 2015 tentang Perubahan Atas Undang-Undang Nomor 1 Tahun 2015 tentang Penetapan Peraturan Pemerintah Pengganti Undang-Undang Nomor 1 Tahun 2014 tentang Pemilihan Gubernur, Bupati, dan Walikota Menjadi Undang-Undang (Lembaran Negara Republik Indonesia Tahun 2015 Nomor 57, Tambahan Lembaran Negara Republik Indonesia Nomor 5678).

14 Pasal 5 ayat (3) Undang-Undang Nomor 8 Tahun 2015 tentang Perubahan Atas Undang-Undang Nomor 1 Tahun 2015 tentang Penetapan Peraturan Pemerintah Pengganti Undang-Undang Nomor 1 Tahun 2014 tentang Pemilihan Gubernur, Bupati, dan Walikota Menjadi Undang-Undang (Lembaran Negara Republik Indonesia Tahun 2015 Nomor 57, Tambahan Lembaran Negara Republik Indonesia Nomor 5678).

15 Penjelasan Undang-Undang Nomor 8 Tahun 2015 tentang Perubahan Atas Undang-Undang Nomor 1 Tahun 2015 tentang Penetapan Peraturan Pemerintah Pengganti Undang-Undang Nomor 1 Tahun 2014 tentang Pemilihan Gubernur, Bupati, dan Walikota Menjadi Undang-Undang (Lembaran Negara Republik Indonesia Tahun 2015 Nomor 57, Tambahan Lembaran Negara Republik Indonesia Nomor 5678).

16 Pasal 41 ayat (1) dan (2) Undang-Undang Nomor 8 Tahun 2015 tentang Perubahan Atas Undang-Undang Nomor 1 Tahun 2015 tentang Penetâpan Peraturan Pemerintah Pengganti Undang-Undang Nomor 1 Tahun 2014 tentang Pemilihan Gubernur, Bupati, dan Walikota Menjadi Undang-Undang (Lembaran Negara Republik Indonesia Tahun 2015 Nomor 57, Tambahan Lembaran Negara Republik Indonesia Nomor 5678).

17 Pasal 166 ayat (1) Undang-Undang Nomor 8 Tahun 2015 tentang Perubahan Atas Undang-Undang Nomor 1 Tahun 2015 tentang Penetapan Peraturan Pemerintah Pengganti Undang-Undang Nomor 1 Tahun 2014 tentang Pemilihan Gubernur, Bupati, dan Walikota Menjadi Undang-Undang (Lembaran Negara Republik Indonesia Tahun 2015 Nomor 57, Tambahan Lembaran Negara Republik Indonesia Nomor 5678).

18 Penjelasan Undang-Undang Nomor 8 Tahun 2015 tentang Perubahan Atas Undang-Undang Nomor 1 Tahun 2015 tentang Penetapan Peraturan Pemerintah Pengganti Undang-Undang Nomor 1 Tahun 2014 tentang Pemilihan Gubernur, Bupati, dan Walikota Menjadi Undang-Undang (Lembaran Negara Republik Indonesia Tahun 2015 Nomor 57, Tambahan Lembaran Negara Republik Indonesia Nomor 5678).

19 Pasal 157 ayat (2) Undang-Undang Nomor 8 Tahun 2015 tentang Perubahan Atas Undang-Undang Nomor 1 Tahun 2015 tentang Penetapan Peraturan Pemerintah Pengganti Undang-Undang Nomor 1 Tahun 2014 tentang Pemilihan Gubernur, Bupati, dan Walikota Menjadi Undang-Undang (Lembaran Negara Republik Indonesia Tahun 2015 Nomor 57, Tambahan Lembaran Negara Republik Indonesia Nomor 5678).

20. Pasal 201 ayat (1) Undang-Undang Nomor 8 Tahun 2015 tentang Perubahan Atas Undang-Undang Nomor 1 Tahun 2015 tentang Penetapan Peraturan Pemerintah Pengganti Undang-Undang Nomor 1 Tahun 2014 tentang Pemilihan Gubernur, Bupati, dan Walikota Menjadi Undang-Undang (Lembaran Negara Republik Indonesia Tahun 2015 Nomor 57, Tambahan Lembaran Negara Republik Indonesia Nomor 5678). 
b. Gelombang kedua dilaksanakan Februari 2017 (untuk akhir masa jabatan semester kedua tahun 2016 dan seluruh akhir masa jabatan 2017). ${ }^{21}$

c. Gelombang ketiga dilaksanakan Juni 2018 (untuk akhir masa jabatan tahun 2018 dan akhir masa jabatan 2019). ${ }^{22}$

d. Serentak nasional dilaksanakan tahun 2027. ${ }^{23}$

10. Pengajuan pencalonan dilakukan secara berpasangan, yaitu pasangan Gubernur \& Wakil Gubernur, Bupati \& Wakil Bupati, dan Walikota \& Wakil Walikota secara paket dalam pemilihan secara langsung oleh rakyat. $^{24}$

11. Tentang tambahan syarat calon kepala daerah yang terkait syarat tidak pernah dipidana, disepakati bahwa rumusannya disesuaikan dengan Putusan Mahkamah
Konstitusi sebagaimana yang tercantum dalam rumusan Perppu Pilkada. ${ }^{25}$

Walaupun UU Pilkada memberikan kejelasan penanganan perselisihan hasil Pilkada pada Mahkamah Agung ${ }^{26}$, namun, salah satu poin yang disahkan dalam revisi UU Pilkada adalah mengembalikan penyelesaian sengketa Pilkada kepada Mahkamah Konstitusi dalam masa transisi sampai dibentuknya lembaga peradilan khusus. Hal ini menunjukkan bahwa terdapat legal importance untuk membentuk sebuah pengadilan khusus yang secara spesifik menangani sengketa Pilkada. Terlebih Mahkamah Agung menyatakan menolak penyelesaian sengketa Pilkada. ${ }^{27}$

Berpijak pada dinamika legislasi kekinian dan desain keserentakan Pilkada yang akan dilaksanakan pada bulan Desember 2015, maka tentu saja diperlukan sebuah piranti hukum yang

$21 \quad$ Pasal 201 ayat (2) Undang-Undang Nomor 8 Tahun 2015 tentang Perubahan Atas Undang-Undang Nomor 1 Tahun 2015 tentang Penetapan Peraturan Pemerintah Pengganti Undang-Undang Nomor 1 Tahun 2014 tentang Pemilihan Gubernur, Bupati, dan Walikota Menjadi Undang-Undang (Lembaran Negara Republik Indonesia Tahun 2015 Nomor 57, Tambahan Lembaran Negara Republik Indonesia Nomor 5678).

22 Pasal 201 ayat (3) Undang-Undang Nomor 8 Tahun 2015 tentang Perubahan Atas Undang-Undang Nomor 1 Tahun 2015 tentang Penetapan Peraturan Pemerintah Pengganti Undang-Undang Nomor 1 Tahun 2014 tentang Pemilihan Gubernur, Bupati, dan Walikota Menjadi Undang-Undang (Lembaran Negara Republik Indonesia Tahun 2015 Nomor 57, Tambahan Lembaran Negara Republik Indonesia Nomor 5678).

23 Pasal 201 ayat (7) Undang-Undang Nomor 8 Tahun 2015 tentang Perubahan Atas Undang-Undang Nomor 1 Tahun 2015 tentang Penetapan Peraturan Pemerintah Pengganti Undang-Undang Nomor 1 Tahun 2014 tentang Pemilihan Gubernur, Bupati, dan Walikota Menjadi Undang-Undang (Lembaran Negara Republik Indonesia Tahun 2015 Nomor 57, Tambahan Lembaran Negara Republik Indonesia Nomor 5678).

24 Pasal 39 Undang-Undang Nomor 8 Tahun 2015 tentang Perubahan Atas Undang-Undang Nomor 1 Tahun 2015 tentang Penetapan Peraturan Pemerintah Pengganti Undang-Undang Nomor 1 Tahun 2014 tentang Pemilihan Gubernur, Bupati, dan Walikota Menjadi Undang-Undang (Lembaran Negara Republik Indonesia Tahun 2015 Nomor 57, Tambahan Lembaran Negara Republik Indonesia Nomor 5678).

25 Penjelasan Pasal 7 huruf g Undang-Undang Nomor 8 Tahun 2015 tentang Perubahan Atas Undang-Undang Nomor 1 Tahun 2015 tentang Penetapan Peraturan Pemerintah Pengganti Undang-Undang Nomor 1 Tahun 2014 tentang Pemilihan Gubernur, Bupati, dan Walikota Menjadi Undang-Undang (Lembaran Negara Republik Indonesia Tahun 2015 Nomor 57, Tambahan Lembaran Negara Republik Indonesia Nomor 5678).

26 Pasal 156-159 Undang-Undang Nomor 1 Tahun 2015 tentang Penetapan Peraturan Pemerintah Pengganti Undang-Undang Nomor 1 Tahun 2014 tentang Pemilihan Gubernur, Bupati, dan Walikota Menjadi UndangUndang (Lembaran Negara Republik Indonesia Tahun 2015 Nomor 23, Tambahan Lembaran Negara Republik Indonesia Nomor 5656).

27 Suryanta Bakti Susila dan Agus Rahmat, "Akan Dibentuk Peradilan Khusus Sengketa Pilkada", http://politik.news. viva.co.id/news/read/590742-akan-dibentuk-peradilan-khusus-sengketa-pilkada, (diakses 11 Maret 2015). 
dapat mendukung pelaksanaan Pilkada serentak tersebut. Salah satunya yang dibutuhkan adalah keberadaan lembaga adjudikasi yang dapat dan mampu menyelesaikan persengketaan dan perselisihan hasil Pilkada. Desain penyelesaian sengketa Pilkada adalah melalui Majelis Khusus Tindak Pidana ${ }^{28}$ dan Majelis Khusus Tata Usaha Negara ${ }^{29}$ yang semula diatur pada UU Pilkada dinilai tidak dapat menjawab kompleksitas Pilkada terlebih dengan penolakan Mahkamah Agung untuk melaksanakan kewenangan tersebut dan "keengganan" Mahkamah Konstitusi dengan "melepaskan" kewenangan tersebut melalui Putusan Mahkamah Konstitusi Nomor 97/PUU-XI/2013 ${ }^{30}$.

Sebelum sengketa Pilkada dilimpahkan ke Mahkamah Agung dalam UU Pilkada, data Mahkamah Konstitusi menyebutkan bahwa sejak Tahun 2008-2014, terdapat 689 gugatan hasil Pilkada yang harus diperiksa Mahkamah Konstitusi dalam waktu singkat. ${ }^{31}$ Terlebih, data Kementerian Dalam Negeri Indonesia menyebutkan bahwa pada tahun 2015 sebagai masa transisi Pilkada serentak jumlah Pilkada yang akan diselenggarakan serentak bertahap mencapai 205 Pilkada. ${ }^{32}$
Untuk menghadapi hal tersebut, dalam UU Pilkada kewenangan penyelesaian sengketa diletakkan sebatas pada Majelis Khusus Tindak Pidana dan Majelis Khusus Tata Negara. Hal yang patut dikritisi karena pembentukan Majelis Khusus Tindak Pidana dan Majelis Khusus Tata Usaha Negara masih menyimpan sisi kelemahan, pasalnya melalui kedua majelis tersebut penyelesaian sengketa Pilkada masih berada pada lembaga-lembaga yang terpisah, yakni di Peradilan Umum dan Peradilan Tata Usaha Negara. Dengan mempertahankan desain tersebut, tantangannya kemudian adalah kesulitan memenuhi ketepatan waktu penyelesaian sengketa yang akan kontraproduktif dengan keharusan penyelesaian sengketa Pilkada untuk diselesaikan dalam waktu singkat.

Berbekal kondisi di atas, harus dipikirkan sebuah lembaga adjudikasi yang mampu menyelesaikan sengketa dan perselisihan Pilkada dengan lebih efisien, efektif, dan berkeadilan. $\mathrm{Hal}$ ini penting untuk menjadikan Pilkada sebagai pesta demokrasi di daerah yang tidak kehilangan makna sebagai semata rangkaian semantis tanpa esensi cita rasa demokratis.

28 Pasal 151 Undang-Undang Nomor 1 Tahun 2015 tentang Penetapan Peraturan Pemerintah Pengganti UndangUndang Nomor 1 Tahun 2014 tentang Pemilihan Gubernur, Bupati, dan Walikota Menjadi Undang-Undang (Lembaran Negara Republik Indonesia Tahun 2015 Nomor 23, Tambahan Lembaran Negara Republik Indonesia Nomor 5656).

29 Pasal 155 Undang-Undang Nomor 1 Tahun 2015 tentang Penetapan Peraturan Pemerintah Pengganti UndangUndang Nomor 1 Tahun 2014 tentang Pemilihan Gubernur, Bupati, dan Walikota Menjadi Undang-Undang (Lembaran Negara Republik Indonesia Tahun 2015 Nomor 23, Tambahan Lembaran Negara Republik Indonesia Nomor 5656).

30 Putusan Mahkamah Konstitusi Nomor 97/PUU-XI/2013 perihal Pengujian Undang-Undang Nomor 12 Tahun 2008 tentang Perubahan Kedua Atas Undang-Undang Nomor 32 Tahun 2004 tentang Pemerintahan Daerah dan Undang-Undang Nomor 48 Tahun 2009 tentang Kekuasaan Kehakiman terhadap Undang-Undang Dasar Negara Republik Indonesia Tahun 1945, hlm. 60.

31 Pendapat Ahmad Fadil Sumadi dalam Putusan Mahkamah Konstitusi Nomor 97/PUU-XI/2013 perihal Pengujian Undang-Undang Nomor 12 Tahun 2008 tentang Perubahan Kedua Atas Undang-Undang Nomor 32 Tahun 2004 tentang Pemerintahan Daerah dan Undang-Undang Nomor 48 Tahun 2009 tentang Kekuasaan Kehakiman terhadap Undang-Undang Dasar Negara Republik Indonesia Tahun 1945.

32 Surat Kementerian Dalam Negeri Republik Indonesia Nomor 120/4474/OTDA perihal Konfirmasi Data Akhir Masa Jabatan Kepala Daerah Tahun 2015, tanggal 29 Oktober 2014. 
Inisiasi pembentukan suatu lembaga adjudikasi khusus sangat tepat dipikirkan sebagai bentuk pembaharuan hukum dalam era otonomi daerah pada masa kepemimpinan JokowiJK saat ini, sebagai bentuk persiapan menuju Pilkada serentak tahun 2020, sehingga ke depan tercipta Pilkada, yang bukan semata demokratis, namun juga berkeadilan.

Berdasarkan latar belakang sebagaimana yang telah dikemukakan di atas, terdapat berbagai rumusan permasalahan, yakni: (a) Bagaimana urgensi pembentukan pengadilan khusus Pilkada di Indonesia? (b) Bagaimana perbandingan pengadilan khusus Pilkada di beberapa negara lain? dan (c) Bagaimana relevansi perbandingan tersebut dapat diterapkan di Indonesia?

\section{B. Metode Penelitian}

\section{Sifat Penelitian}

Penulisan ini merupakan penelitian hukum (legal research) dikarenakan secara spesifik menggunakan logika berpikir hukum dalam menganalisis permasalahan. Penelitian hukum ini berfokus mengkaji urgensi dan relevansi pengadilan khusus Pilkada sebagai sebuah inisiasi yang diperlukan untuk memprevensi penyelesaian sengketa dalam keserentakan Pilkada di Indonesia. Lebih lanjut dalam rangka mendapatkan informasi yang diperlukan dalam penelitian ini, sehingga dapat digunakan untuk menganalisis permasalahan hukum yang sedang dikaji, maka digunakan beberapa pendekatan yang lazim digunakan dalam penelitian hukum, yaitu pendekatan perundang-undangan (statute approach), pendekatan kasus (case approach), dan pendekatan konseptual (conceptual approach). ${ }^{33}$ Pendekatan-pendekatan tersebut digunakan untuk menjawab fokus penelitian.

Beberapa pendekatan yang digunakan dalam penelitian ini adalah: Pertama, pendekatan perundang-undangan (statute approach). Penelitian hukum dalam level dogmatik hukum atau penelitian untuk keperluan praktik hukum tidak dapat melepaskan diri dari pendekatan peraturan perundang-undangan. ${ }^{34}$ Dalam penelitian hukum ini, dikarenakan terkait dengan penyelesaian sengketa Pilkada, maka dirujuk berbagai peraturan yang terkait dengan kekuasaan kehakiman dan pemerintahan daerah merupakan suatu pendekatan yang mutlak harus digunakan. Perspektif peraturan perundang-undangan digunakan untuk menilai bagaimana pengaturan mengenai penyelesaian sengketa Pilkada yang didesainkan saat ini sebagai titik fokus penelitian ini.

Kedua, pendekatan konseptual (conceptual approach). Setelah mengetahui mengenai desain pengaturan, maka selanjutnya penelitian bergeser menggunakan pendekatan konseptual untuk menilai dan memahami bagaimana aspek teoritis terhadap konsepsi penyelesaian sengketa Pilkada. Pendekatan konseptual beranjak dari pandangan-pandangan dan doktrin-doktrin yang berkembang di dalam ilmu hukum. ${ }^{35}$ Ketiga, pendekatan kasus (case approach). Pendekatan kasus dalam penelitian ini digunakan untuk menilai praktik penyelesaian sengketa Pilkada di beberapa negara. Dengan demikian, dapat dilihat praktik terbaik (best practices) dari pengadilan khusus dalam menyelesaikan sengketa Pilkada atau yang sejenis.

\footnotetext{
33 Peter Mahmud Marzuki, Penelitian Hukum (Jakarta: Kencana, 2005), hlm. 93.

34 Ibid., hlm. 96.

35 Ibid., hlm. 95.
} 


\section{Cara Penelitian}

Meminjam klasifikasi yang dibuat oleh Amiruddin dan Zainal Asikin, maka penelitian hukum ini pada dasarnya digolongkan dalam penelitian hukum normatif, ${ }^{36}$ karena dalam penelitian hukum ini, hukum dikonsepkan sebagai apa yang tertulis dalam peraturan perundang-undangan (law in books) atau hukum dikonsepkan sebagai kaidah atau norma yang merupakan patokan berperilaku manusia yang dianggap pantas. ${ }^{37}$ Dalam kategorisasi yang lain menurut Ronny Hanitijo Soemitro, penelitian ini dapat dikategorikan dalam penelitian hukum normatif terhadap asas-asas hukum. ${ }^{38}$ Dalam penelitian hukum normatif digunakan penelitian hukum kepustakaan, ${ }^{39}$ yaitu mendapatkan data sekunder dengan bahan atau materi berupa buku, artikel, hasil penelitian, dan peraturan perundang-undangan, serta pendapat ahli yang berkaitan tentang berkaitan dengan fokus penelitian.

\section{Jenis Data}

Sebagaimana telah disebutkan di atas bahwa penelitian ini adalah penelitian hukum normatif yang menitikberatkan pada penelitian hukum kepustakaan. Oleh karena itu, salah satu ciri utama dari penelitian hukum kepustakaan adalah menggunakan sumber data sekunder, yang terdiri dari bahan hukum primer, bahan hukum sekunder, dan bahan hukum tersier. ${ }^{40}$ Bahan Hukum Primer, yaitu bahan-bahan hukum atau ketentuan yang mengikat, ${ }^{41}$ dan peraturan perundang-undangan yang pernah berlaku yang berkaitan dengan objek penelitian.

Bahan Hukum Sekunder, yaitu bahan yang memberikan penjelasan mengenai bahan-bahan hukum primer, ${ }^{42}$ atau teks yang berisi mengenai prinsip-prinsip dasar ilmu hukum dan pandangan-pandangan klasik para sarjana yang mempunyai kualifikasi tinggi, ${ }^{43}$ atau bahan-bahan yang erat hubungannya dengan bahan hukum primer dan dapat membantu menganalisa dan memahami bahan hukum primer, ${ }^{44}$ antara lain semua dokumen yang terkait obyek penelitian yang tersebar dalam buku, majalah, surat kabar atau internet, makalah hasil seminar, dan hasil penelitian terdahulu yang sejenis dengan obyek penelitian. Sedangkan, Bahan Hukum Tersier, mencakup bahan-bahan yang memberikan petunjuk terhadap bahan hukum primer dan hukum sekunder. ${ }^{45}$

\section{Analisis Data}

Analisis data sebagai tindak lanjut proses pengolahan data merupakan kerja seorang peneliti yang memerlukan ketelitian, dan pencurahan daya pikir secara optimal. ${ }^{46}$ Analisis

\footnotetext{
Amiruddin dan Zainal Asikin, Pengantar Metode Penelitian Hukum (Jakarta: RajaGrafindo Persada, 2004), hlm. 29.

37 Ibid., hlm. 118.

38 Ronny Hanitijo Soemitro, Metodologi Penelitian Hukum dan Jurimetri (Jakarta: Ghalia Indonesia, 1988$)$, hlm. 15.

39 Soerjono Soekanto dan Sri Mamudji, Penelitian Hukum Normatif Suatu Tinjauan Umum (Jakarta: RajaGrafindo Persada, 2007), hlm. 23.

40 Amiruddin dan Zainal Asikin, Loc.cit.

Peter Mahmud Marzuki, Op.cit., hlm. 142.

44 Ronny Hanitijo Soemitro, Metodologi Penelitian Hukum (Jakarta: Ghalia Indonesia, 1985), hlm. 25.

45 Soerjono Soekanto dan Sri Mamudji, Op.cit., hlm. 33.

46 Bambang Waluyo, Penelitian Hukum dalam Praktik (Jakarta: Sinar Grafika, 2002), hlm. 77.
}

41 Ibid.

42 Ibid. 
data berisi uraian tentang cara-cara analisis, yaitu bagaimana memanfaatkan data yang terkumpul untuk dipergunakan dalam memecahkan masalah penelitian atau merupakan penjelasan mengenai proses memanfaatkan data yang terkumpul untuk selanjutnya digunakan dalam memecahkan masalah penelitian. ${ }^{47}$

Metode pengolahan data yang digunakan adalah dengan mengumpulkan data yang diperoleh dari penelitian kepustakaan, yang kemudian diolah menggunakan metode kualitatif. Sebagai penelitian hukum normatif, maka data yang terkait dengan penulisan hukum ini dianalisis secara deskriptif kualitatif, yaitu dengan melakukan analisis yang pada dasarnya dikembalikan pada tiga aspek, yaitu mengklasifikasi, membandingkan, dan menghubungkan. ${ }^{48}$ Dengan perkataan lain, seorang peneliti yang mempergunakan metode kualitatif, tidaklah semata-mata bertujuan mengungkapkan kebenaran belaka, akan tetapi untuk memahami kebenaran tersebut. ${ }^{49}$ Suatu analisis yuridis normatif pada hakikatnya menekankan pada metode deduktif sebagai pegangan utama, ${ }^{50}$ yaitu proses berpikir yang dimulai dari pernyataan yang umum menuju pernyataan yang khusus (spesifik) dengan menggunakan logika yang dapat diterima.

Selain itu, dalam mengolah dan menganalisis data yang ada, Peneliti juga menggunakan penafsiran (interpretasi) yang dikenal dalam ilmu hukum. Penafsiran tersebut diperlukan dalam rangka penggalian makna, sehingga apa yang dibaca bukan hanya diartikan secara tekstual, namun dimaknai secara kontekstual untuk menggali makna baik yang tersurat maupun yang tersirat. Ketepatan pemahaman (subtilitas intellegendi) dan ketepatan penjabaran (subtilitas explicandi) adalah sangat relevan bagi hukum. ${ }^{51}$

\section{Pembahasan}

\section{Urgensi Pembentukan Pengadilan Khusus Pilkada}

Gagasan mengenai pengadilan khusus Pilkada menjadi hal yang relevan untuk dipertimbangkan karena upaya hukum dalam proses Pilkada yang telah terjadi selama ini seringkali tidak dapat memenuhi rasa keadilan masyarakat, misalnya putusan pengadilan yang baru diputus pasca tahapan Pilkada telah selesai dilaksanakan dan berlapis-lapisnya upaya hukum Pilkada sehingga kontraproduktif dengan tahapan Pilkada yang dibatasi oleh jangka waktu. Terlebih upaya hukum tersebut terpisah dalam beberapa lingkungan peradilan. Dengan kondisi tersebut, upaya hukum terhadap tahapan Pilkada menghadapi tantangan lebih lanjut dengan pelaksanaan Pilkada serentak karena tahapan proses pemilihan dan upaya hukum atas setiap tahapan pemilihan tersebut akan dilaksanakan secara bersamaan, sehingga bila menggunakan mekanisme peradilan sebagaimana hukum positif saat ini tentu mewujudkan Pilkada yang berkeadilan akan sulit untuk diwujudkan.

7 Maria S.W. Sumardjono, Pedoman Pembuatan Usulan Penelitian: Sebuah Panduan Dasar (Jakarta: Gramedia, 2001), hlm. 38.

48 Jujur S. Suriasumantri, Ilmu dalam Perspektif Moral, Sosial dan Politik: Sebuah Dialog tentang Keilmuan Dewasa Ini (Jakarta: Gramedia, 1986), hlm. 61-62.

49 Soerjono Soekanto, Op.cit., hlm. 250.

50 Ibid., hlm. 164.

51 Ibid., hlm. 164. 
Hal yang patut dikritisi adalah bahwa pembentukan Majelis Khusus Tindak Pidana dan Majelis Khusus Tata Usaha Negara masih menyimpan sisi kelemahan karena melalui kedua majelis tersebut penyelesaian sengketa pilkada masih berada pada lembagalembaga yang terpisah, yakni di Peradilan umum dan Peradilan Tata Usaha Negara. Dengan mempertahankan desain tersebut, tantangannya kemudian adalah kesulitan memenuhi ketepatan waktu penyelesaian sengketa yang akan kontraproduktif dengan keharusan penyelesaian sengketa Pilkada untuk diselesaikan dalam waktu singkat.

Patut diingat, sebelum Pilkada diselenggarakan secara serentak saja, permasalahan ketepatan waktu putusan lembaga adjudikasi menjadi hal yang menyebabkan gagalnya negara memenuhi hak konstitusional warga negara. Sebagai contoh adalah pada kasus gugatan PTUN yang diajukan oleh Rudolf Pardede dan Affifudin Lubis di Kota Medan. Pada waktu itu, Putusan PTUN dikeluarkan ketika telah melewati rentang penetapan pasangan calon, padahal gugatan yang diajukan oleh Rudolf Pardede dan Affifudin Lubis adalah tentang hak mereka untuk ditetapkan sebagai pasangan calon. ${ }^{52}$ Akhirnya Putusan PTUN tersebut tidak dieksekusi oleh KPU Kota Medan dengan alasan tahap penetapan calon sudah lewat. Yang lebih menyebabkan kacau, Putusan TUN tersebut bahkan beberapa kali mendasari permohonan Pemohon sebagai bakal calon kepala daerah untuk memiliki legal standing berperkara di Mahkamah Konstitusi.

\section{Pengadilan Khusus Pemilu di Beberapa Negara}

Dalam mendesain Pengadilan Khusus Pilkada di Indonesia, perlu dikaji beberapa komparasi dengan berbagai negara yang telah memiliki pengadilan pemilu. Berdasarkan penelusuran Penulis, terdapat banyak negara yang telah menerapkan Pengadilan Pemilu, seperti Uruguay, Brazil, Costa Rica, Nigeria, dan Meksiko. Negara-negara di Amerika Latin dan Afrika tersebut mayoritas menggabungkan kewenangan administrasi pemilu (election administration) dengan adjudikasi sengketa (election complaints adjudication). ${ }^{53}$ Dengan memperhatikan konteks desain kekuasaan kehakiman dan kelembagaan penyelenggara Pemilu, maka Penulis memilih 3 (tiga) negara yang relatif relevan untuk dijadikan perbandingan dalam menginisiasi Pengadilan Pemilu, yakni Uruguay, Brazil, dan Costa Rica.

\section{a) Corte Electoral di Uruguay}

República Oriental del Uruguay merdeka pada tahun 1825 memiliki kombinasi quasipresidentialism dan sistem multipartai. Electoral Law 1924 menandai terbentuknya badan manajemen pemilu yang otonom dan mandiri, yang sebelumnya hampir satu abad penyelesaian sengketa berada di tangan eksekutif, akhirnya dibentuk yurisdiksi Corte Electoral (Pengadilan Pemilu) yang independen dan permanen, yang mana pada tahun 1934 keberadaan dan kewenangan Pengadilan Pemilu yang dituangkan dalam Konstitusi Uruguay. 
Sejak tahun 1924, Uruguay merupakan negara yang telah memiliki pengadilan khusus untuk menangani sengketa pemilu. ${ }^{54}$ Ini menunjukkan bahwa Uruguay sudah cukup lama mendirikan pengadilan pemilu, sehingga relevan bagi Indonesia untuk menjadikannya sebagai benchmarking ketika akan mendirikan pengadilan pemilu. Selain alasan tersebut, Uruguay juga memiliki beberapa kesamaan karakter dengan Indonesia, yakni menganut sistem multi partai. Mekanisme Pemilu di Uruguay pun bertingkat sesuai wilayah, yakni Pemilu di tingkat negara dan Pemilu di tingkat Departamental ${ }^{55}$, sama dengan Indonesia yang memiliki mekanisme Pemilu di tingkat nasional dan Pemilu di tingkat daerah.

Secara kelembagaan, Electoral Court di Uruguay berdiri secara permanen dan terdiri dari Pengadilan Pemilu di tingkat nasional yang disebut Electoral Court dan Pengadilan Pemilu di tingkat daerah yang disebut dengan Electoral Boards (Juntas Electorales). ${ }^{56}$ Masing-masing dari Electoral Court dan Electoral Boards dibantu oleh kantor sekretariat yang khusus menangani permasalahan administratif seperti pegawai dan segala hal terkait pembiayaan Pengadilan Pemilu. Kantor sekretariat ini di tingkat nasional disebut National Electoral Office, sedangkan di tingkat lokal disebut Departmental Electoral Office. ${ }^{57}$ Dikarenakan bersifat subordinat antara organisasi tingkat nasional dan Departemen, maka Electoral Boards wajib selalu melaporkan kegiatannya pada Electoral Court, demikian pula Departmental Electoral Office diwajibkan melaporkan kegiatannya pada National Electoral Office. ${ }^{58}$

Kewenangan dari Electoral Court sebagaimana disebutkan dalam Konstitusi Uruguay mencakup 3 (tiga) hal, yakni: (a) bertanggung jawab membuat peraturan tentang pemilu dan mengawasi pelaksanaannya (to act in all matters relating to electoral acts or procedures); (b) menjadi pusat koordinasi segala hal terkait pemilu termasuk mengenai pembiayaan pemilu (to exercise directive, disciplinary, advisory, and economic supervision over electoral organs); dan (3) Memutus sengketa hasil pemilu (to render final decision on all appeals and claims that may arise and act as judge of the elections to all elective offices, and of plebiscites and referendums). ${ }^{59}$

Dikarenakan bersifat subordinat, maka kewenangan Electoral Boards merupakan bagian kewenangan Electoral Court yang terbatas pada level daerah. Kewenangan Pengadilan Pemilu di Uruguay tersebut tampak sangat luas mencakup segala hal terkait pemilu mulai dari pembuatan regulasinya, pelaksanaannya, sampai penyelesaian sengketanya. Hal ini kemudian menjadikan Pengadilan Pemilu Uruguay diistilahkan sebagai cabang keempat negara karena mampu mengambil alih fungsi legislatif, eksekutif, dan yudikatif. ${ }^{60}$

\footnotetext{
54 Country Studies US, "The Consolidation of Political Democracy", http://countrystudies.us/uruguay/13.htm, (diakses 4 Maret 2015).

55 Departamental adalah wilayah setingkat dengan Provinsi.

56 Chad Vickery (Ed.), Op.cit., hlm. 124.

57 Sara Staino, "Case Study: Uruguay: The Electoral Court - A Fourth Branch of Government?", dalam Alan Wall, et al., Electoral Management Design: The International IDEA Handbook (Stockholm: IDEA, 2006), hlm. 219.

58 Ibid.

59 Article 322 of the Constitution of Uruguay 1966 (reinst. 1985, rev. 2004).

60 Sara Staino, "Case Study: Uruguay: The Electoral Court - A Fourth Branch of Government?", Loc.cit.
} 
Electoral Court memiliki anggota berjumlah 9 (sembilan) orang yang dipilih oleh anggota 2 (dua) kamar Parlemen Uruguay. ${ }^{61}$ Sembilan orang ini, lima merupakan orang-orang nonpartai politik yang dipilih berdasarkan keahlian profesional (based on professional skill). ${ }^{62}$ Untuk dapat menentukan lima orang terpilih tersebut, pemungutan suara di parlemen harus setidaktidaknya mampu mengumpulkan $2 / 3$ suara keseluruhan anggota.63 Sedangkan untuk menentukan empat orang anggota sisanya, mekanismenya dilakukan melalui pemilihan dengan sistem proporsional oleh anggota partai politik pemimpin dalam parlemen. ${ }^{64}$

\section{b) Tribunal Superior Eleitoral di Brazil}

Penegakan hukum Pemilu di Brazil baru mulai dengan pembentukan Pengadilan Khusus Pemilu pada tahun 1932, walaupun Pemilu pertama di Brazil dilaksanakan pada tahun 1821 ketika Brazil masih menjadi negara jajahan Portugis. ${ }^{65}$ Brazil memiliki dua jenis Pemilu, yakni Pemilu di tingkat negara federal dan Pemilu di wilayah negara bagian. Diperbandingkan dengan Indonesia yang berbentuk negara kesatuan, tentu mekanisme Pemilunya berbeda, namun dilihat dari sistem kepartaian baik Indonesia maupun Brazil memiliki kesamaan menganut multipartai, sehingga hal ini pun akan berpengaruh terhadap jalannya Pemilu.
Pengadilan Pemilu di Brazil merupakan bagian dari Electoral Justice System, yaitu: (a) Superior Electoral Tribunal; (b) Regional Electoral Tribunals; (c) Electoral Judges; dan (d) Electoral Boards. ${ }^{66}$ Pengadilan Pemilu di Brazil dibentuk secara permanen dalam 2 (dua) tingkat, yakni pengadilan pemilu di tingkat negara federal yang disebut Superior Electoral Tribunal dan Regional Electoral Tribunals di setiap negara bagian ${ }^{67}$. Pengadilan Pemilu di Brazil merupakan penggabungan dari badan adjudikatif (adjudicative body) dan badan manajemen Pemilu (electoral management body). 68

Komposisi hakim pada Superior Electoral Tribunal terdiri dari 7 (tujuh) hakim dengan komposisi 5 (lima) hakim, yang dipilih 3 (tiga) hakim dari Supreme Federal Tribunal dan 2 (dua) hakim dari Superior Tribunal of Justice, sedangkan 3 (dua) hakim lagi ditunjuk oleh Presiden dengan latar belakang advokat. ${ }^{69}$ Sedangkan hakim pada Regional Electoral Tribunal terdiri dari 7 (tujuh) hakim dengan komposisi 4 (empat) hakim, yang dipilih 2 (dua) hakim dari Tribunals of Justice dan 2 (dua) hakim dari pengadilan negara bagian yang ditunjuk oleh Tribunals of Justice, sedangkan komposisi 3 (tiga) hakim, yang dipilih 1 (satu) hakim dari Federal Regional Tribunal dan 2 (dua) hakim lagi ditunjuk oleh Presiden dengan latar belakang advokat. $^{70}$

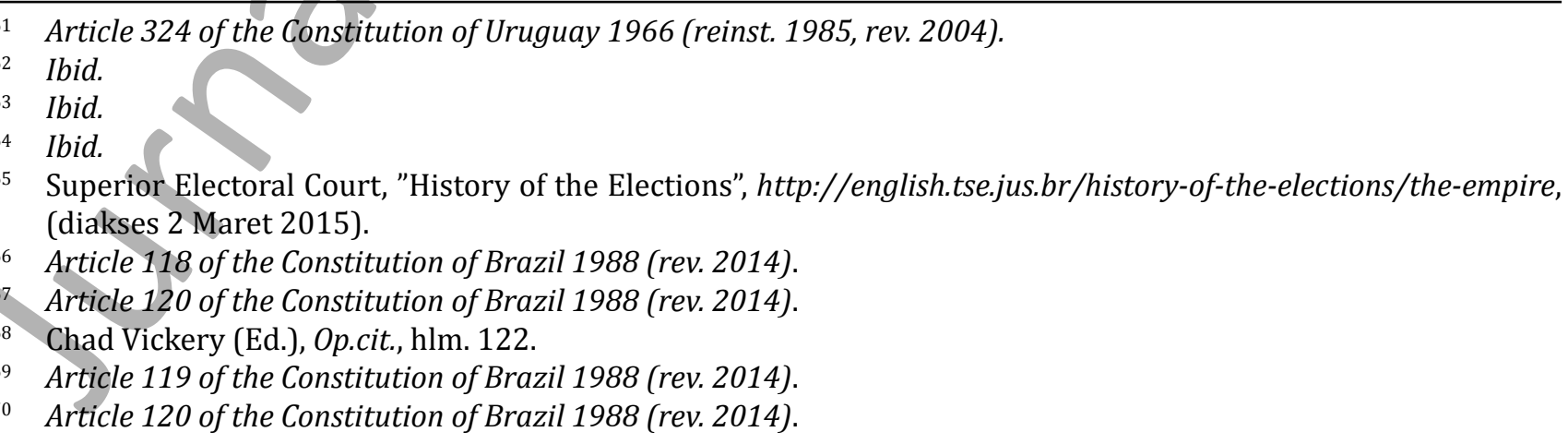


Putusan Superior Electoral Tribunal tidak dapat diajukan banding, sehingga bersifat final dan mengikat. ${ }^{71}$ Adapun demikian terdapat pengecualian putusan-putusan yang dapat diajukan banding, yaitu: (a) they contravene an express provision of this Constitution or law; (b) a divergence exists in the interpretation of a law between two or more electoral courts; (c) they deal with ineligibility or issuance of certificates of election in federal or state elections; (d) they annul certificates of election or decree the loss of federal or state elective offices; dan (e) they deny habeas corpus, writ of security, habeas data or a mandate of injunction. ${ }^{72}$

\section{c) Tribunal Supremo de Elecciones di Costa Rica}

Tribunal Supremo de Elecciones berdiri tahun 1946 dan dimasukkan dalam Konstitusi Costa Rica pada tahun 1949 dan diberikan kekuasaan penuh untuk menyelenggarakan Pemilu Pemilu Presiden, Pemilu Legislatif, dan Pemilu Lokal. ${ }^{73}$ Hal tersebut menunjukkan bahwa tipologi Pemilu yang ada di Costa Rica relatif hampir sama dengan Indonesia. Selain itu, Costa Rica juga menganut sistem pemerintahan presidensial ${ }^{74}$ dengan sistem multipartai. Ditinjau dari sisi ini, maka komparasi antara Indonesia dan Costa Rica menjadi relevan untuk dilakukan.

Jika ditinjau dari sisi kewenangan, Pengadilan ini mirip dengan Uruguay maupun Brazil yang memiliki kewenangan menggabungkan urusan administrasi pemilu maupun urusan adjudikasi pemilu, yang secara eksplisit disebutkan dalam Konstitusi Costa Rica. ${ }^{75}$ Berdasarkan luasnya kewenangan yang dimiliki oleh Tribunal Supremo de Elecciones, pengadilan ini dikenal sebagai the Most Prestigious Institutions in the Country karena menjalankan dan mengkoordinasikan segala hal terkait Pemilu mulai dari menjadi lembaga legislatif, eksekutif, hingga yudikatif. ${ }^{76}$

Kewenangan ini makin bertambah besar karena putusan Tribunal Supremo de Elecciones bersifat final sehingga tidak dapat diganggu gugat. ${ }^{77}$ Namun demikian, dengan kewenangan besar tersebut Pengadilan ini tetap dikelola secara mandiri, imparsial, dan transparan. ${ }^{78}$ Dalam menjalankan kewenangan Tribunal Supremo de Elecciones tersebut terdapat hakim yang terdiri dari 9 (sembilan) hakim utama dengan 6 (enam) hakim pengganti yang dipilih oleh Supreme Court of Justice. ${ }^{79}$

\section{Relevansi Perbandingan Pengadilan Khusus Pemilu untuk Diterapkan Menjadi Desain Pengadilan Khusus Pilkada di Indonesia}

Berdasarkan pada perbandingan Uruguay, Brazil, dan Costa Rica yang telah membentuk Pengadilan Khusus Pemilu, hal ini menunjukkan bahwa kelembagaan adjudikasi khusus untuk Pemilu bukanlah sebuah hal yang tabu untuk diadakan. Terlebih dengan beberapa kesamaan

\footnotetext{
Article 120 paragraph (3) of the Constitution of Brazil 1988 (rev. 2014).

Article 120 paragraph (4) of the Constitution of Brazil 1988 (rev. 2014).

Chad Vickerey (Ed.), Op.cit., hlm. 122.

Article 130 of the Constitution of Costa Rica 1949 (rev. 2011).

Article 102 of the Constitution of Costa Rica 1949 (rev. 2011).

76 Rubén Hernández Valle, "Case Study: Costa Rica: A Powerful Constitutional Body", dalam Alan Wall, et al., Electoral Management Design: The International IDEA Handbook (Stockholm: IDEA, 2006), hlm. 77.

7 Article 102 of the Constitution of Costa Rica 1949 (rev. 2011).

78 Chad Vickerey (Ed.), Op.cit., hlm. 123.

79 Article 100 of the Constitution of Costa Rica 1949 (rev. 2011).
} 
yang dimiliki, baik dari sistem pemerintahan, desain konstitusionalisme, atau bahkan kemapanan dan konsolidasi demokrasi, ${ }^{80}$ perbandingan di atas relevan untuk menjadi benchmarking bagi Indonesia dalam mendesain pengadilan khusus Pilkada, yang tentu saja memiliki identitas ciri tertentu sebagai bentuk rekayasa hukum (legal engineering) dalam praktik ketatanegaraan Indonesia. Rekayasa hukum ini diharapkan dapat membuat konstruksi hukum untuk menuntaskan kebutuhan praktis. ${ }^{81}$

Penggunaan istilah legal engineering merupakan sebuah terminologi yang belum jamak dikenal oleh ahli hukum di Indonesia. Secara sederhana sebenarnya terminologi legal engineering atau rekayasa hukum dipergunakan untuk menggambarkan bagaimana hukum membentuk perubahan sosial. ${ }^{82}$ Jan M. Smits memberikan pemaknaan atas legal engineering sebagai berikut, "As social engineering refers to our ability to engineer a social process (to change society), legal engineering refers to such social engineering through law." ${ }^{83}$

Pola pikir rekayasa hukum sejatinya berpedoman dari perspektif comparative law yang berusaha membuat alternatif solusi dengan memperbandingkan hukum. Dalam hal ini, dari legal engineering (rekayasa hukum) diwujudkan dalam dua nomenklatur, yaitu legal transplants ${ }^{84}$ (transplantasi hukum) dan legal bridges $^{85}$ (jembatan hukum), sebagai produk yang dihasilkan oleh penelitian hukum komparatif (comparative law research)..$^{85} \mathrm{Hal}$ tersebut sejalan dengan pendapat Roscoe Pound yang menyatakan, "history of a system of law is largely a history of borrowings of legal materials from other legal systems and of assimilation of materials from outside of the law". ${ }^{86}$ Bahwa sistem hukum sebagian besar

80 Chad Vickerey (Ed.), Op.cit., hlm. 125. Lihat juga Denis Petit, "Resolving Election Disputes in the OSCE Area: Towards a Standard Election Dispute Monitoring System", (ODIHR Rule of Law Expert, Warsaw, 2000).

81 Eleanor Cashin Ritaine, "Legal Engineering in Comparative Law - An Introduction", dalam Eleanor Cashin Ritaine (Ed.), Legal Engineering and Comparative Law (L'ingénierie juridique et le droit comparé) (Genève: Schulthess, 2009), hlm. 9.

82 John H. Beckstrom, "Handicaps of Legal-Social Engineering in a Developing Nation", American Journal of Comparative Law 22: 4 (1974): 697. Lebih lanjut lihat dalam Harry V. Ball dan Lawrence M. Friedman, "The Use of Criminal Sanctions in the Enforcement of Economic Legislation: A Sociological View", Stanford Law Review 17:2, (Jan., 1965): 220.

83 Jan M. Smits, "Legal Engineering in an Age of Globalisation: Is There a Future for Jurisdictional Competition?", dalam Eleanor Cashin Ritaine (Ed.), Legal Engineering and Comparative Law (L'ingénierie juridique et le droit comparé) (Genève: Schulthess, 2009), hlm. 52.

84 Máximo Langer memilih untuk menggunakan metafora "legal translation", dengan alasan, "The metaphor of the "legal transplant" has been the main device used by comparative law scholars and practitioners when analysing the importation of foreign legal practices. This metaphor, however, has its shortcomings. Its chief problem is that it conveys the notion that legal ideas and institutions can simply be "cut and pasted" between legal systems. Thus, this metaphor fails to account for the transformation that legal ideas and institutions may undergo when they are transferred between legal systems. In this Article, I propose the metaphor of the "legal translation" as an alternative heuristic device to employ when analysing the transfer of legal ideas and institutions between legal systems. The adversarial and the inquisitorial systems, understood as two different procedural cultures, can be understood as two different systems of production of meaning. Thus, the transfer of legal institutions from one system to the other can be understood as translations from one system of meaning to the other." Lihat dalam Máximo Langer, "From Legal Transplants to Legal Translations: The Globalization of Plea Bargaining and the Americanization Thesis in Criminal Procedure", Harvard International Law Journal 45: 1 (Winter 2004): 5.

85 Ibid., hlm. 21-22.

86 Roscoe Pound, The Formative Era of American Law, (Boston: Little, Brown, and Co., 1938), hlm. 94. 
merupakan "pinjaman" dari sistem hukum lain dan percampuran dengan hal-hal di luar hukum.

Transplantasi hukum dipilih oleh suatu negara akan berdampak pada kehidupan sosial ekonomi negara tersebut dengan melihat legal effectiveness ${ }^{87}$ sebagai suatu long term effect penerapan transplantasi hukum yang dipilih. Hal tersebut relevan, mengingat yang dapat ditransplantasikan antara lain berupa institusi (institutions), kebijakan (policies), program (programmes), prosedur (procedures), ideologi (ideologies), pembenaran (justifications), sikap (attitudes), dan ide (ideas). ${ }^{88}$ Pada sisi yang lain, pilihan untuk melakukan transplantasi hukum haruslah didesain dengan cermat untuk menghindari adanya kegagalan atau bahkan penolakan dari sistem yang hendak ditransplantasikan. ${ }^{89}$

Dalam konteks berpikir hukum publik, secara sederhana legal transplants dapat dikatakan sebagai bentuk insersi dari foreign legat solutions terhadap sistem hukum negara lain, atau dapat disebut juga sebagai legal import ${ }^{90}$. Namun, tentu hal ini menjadi hal yang sensitif dikaitkan dengan perspektif kedaulatan negara. Bagaimanapun hukum merupakan bentuk dari kedaulatan rakyat sebagai unsur yang tidak terpisahkan dari negara. Memasukkan solusi hukum asing ke dalam suatu negara harus dengan sangat hati-hati dan harus disesuaikan dengan kekhasan hukum negara penerima.

Spesifik dalam konteks penelitian ini, sejatinya adalah sebuah inisiasi pemikiran untuk mengadopsi sistem yang diterapkan di negara lain dan yang dianggap baik serta mampu memberikan solusi atas permasalahan hukum di Indonesia dalam penyelesaian sengketa Pilkada dengan tetap mengedepankan aspek kompatibilitas dan akseptabilitas dalam sistem hukum Indonesia. Pierre Legrand meneguhkan mengenai ketatnya penerapan transplantasi hukum yang harus menyesuaikan dengan social context suatu negara. ${ }^{91}$ Untuk itu transplantasi hukum tidak dapat melenceng dari desain sistem hukum di suatu negara.

Dalam mendesain kelembagaan adjudikasi, International Institute for Democracy and Electoral Assistance (International IDEA)

87 Jan Torpman dan Fredrik Jörgensen menjelaskan tentang "legal effectiveness" sebagai berikut: "A legal norm is effective in a population of users if users feel confident in their ability to use legal terminology with relevance for the norm, and feel confident that their communication will be accepted as law." Lihat dalam Jan Torpman dan Fredrik Jörgensen, "Legal Effectiveness: Theoretical Developments Concerning Legal Transplants", Archiv Für Rechts und Sozialphilosophie 4 (2005): 22.

88 Martin De Jong dan Virginie Mamadouh, "Two Contrasting Perspectives on Institutional Transplantation", dalam Martin De Jong, Konstantinos Lalenis, dan Virginie Mamadouh (Eds.), The Theory and Practice of Institutional Transplantation: Experiences with the Transfer of Policy Institutions (Dordrecht, The Netherlands: Kluwer Academic Publications, 2002), hlm. 21.

89 Jeremy J. Kingsley menjelaskan potensi kegagalan tersebut dengan menyatakan, "Legal transplants are often unsuccessful if external forces, such as international institutions, assume certain institutional, cultural, or political realities that in fact are not present or properly developed; therefore, these laws are often simply ignored or rejected." Jeremy J. Kingsley, "Legal Transplantation: Is This What the Doctor Ordered and are the Blood Types Compatible? The Application of Interdisciplinary Research to Law Reform in the Developing World - A Case Study of Corporate Governance in Indonesia", Arizona Journal of International and Comparative Law 21:2 (2004): 511. Lihat juga Gary Goodpaster, "The Rule of Law, Economic Development and Indonesia", dalam Timothy Lindsey (Ed.), Indonesia: Law and Society (Sydney: The Federation Press, 1999), hlm. 21-24.

90 Jan M. Smits, "Import and Export of Legal Models: The Dutch Experience", Loc.cit.

91 Pierre Legrand, "The Impossibility of Legal Transplants", Maastricht Journal of European and Comparative Law 4:2 (1997): 121. 
memberikan patokan umum bahwa harus

dikenali terlebih dahulu sifat dan tingkat

keseriusan pembeda sengketa yang timbul dari
Pemilu (recognizing the varying nature and seriousness of different types of complaints and disputes arising from election $)^{92}$. Dalam konteks

92 Chad Vickerey (Ed.), Op.cit., hlm. 126-129. Rekomendasi kriteria dalam pelembagaan adjudikasi Pemilu, yaitu:

a) Election complaints body formation: The election complaints adjudication body is usually referred to as a Complaints Commission, Tribunal, Court, Panel, or other name that reflect its quasi-judicial character. [...] The legislation establishing the complaints body must also specify the number, method of appointment and term of its member, its independence, jurisdiction and powers.

b) Clear jurisdiction: The establishing legislation for the election complaints adjudication body should be clear and should define the following: standing; the required burden of proof for complaints and the nature and sufficiency of evidence; and the jurisdiction of the bodies handling various aspects of the elections process.

c) Independence: The appearance and reality of independence of an election complaints authority derives from the provisions of the law under which it is established; the method of appointment of its members; the professional experience and standing of members; the security the security of funding it receives; its ability to hire and retain competent professional staff who support its independence; and the public respect it gains from the credibility of its election processes. The inclusion of the word "independent" in the provision that establishes the election complaints authority is most important.

d) Membership: Members should ideally be appointed to ensure that they are non-partisan, or, if that is not possible, that the political influence is balanced. Nominations by political parties lead inevitably to politicization and are not recommended. Appropriate nominators include: the courts; an association of universities; a well-established human rights organization; the law society; a national business association; or a national labor organization.

e) Terms of appointment: The term of appointment should be sufficient to encompass preparation and training before the election to the resolution of complaints after the election. Between elections, members should be available on a day-by-day basis for approving reports and making decisions regarding permanent staff, among other duties. Continuity of records and staff expertise would be maintained by the few key staff that would remain.

f) Member characteristics: As an election complaints authority has a quasi-judicial role, its members are usually senior judges or lawyers. In many countries, the amount of time needed for this work would not prevent a judge or lawyer from taking an appointment and maintaining a permanent position as a judge or practicing lawyer. In other countries, the extent and complexity of elections would necessitate a leave of absence.

g) Funding: The electron complaints authority should be funded by an annual budget that comes from the legislature and should not be rooted through the Ministry of Finance. This prevents the governing party from having an undue influence on the budget and places its review before an open, public and multi-party committee.

h) Procedural clarity: The established procedures for the election complaints authority should be clear about the rules for filing an action and provide unambiguous definitions of standing and burdens of proof for specific allegations.

i) Legitimacy: If an election complaints authority functions well, issues clear reports of just decisions, applies proper sanctions and reports serious cases for prosecution. Its own record will establish the public respect that is the best support of independence. This reflects back to the reporting and public information role the key permanent staff can play between elections.

j) Continuity in non-election years: The function of the permanent staff between elections should be to complete and publish the records of the determination of complaints in the past election; review and improve procedures and systems to deal with complaints; participate in public information programs on elections: keep informed on changes in the election process; administer occasional maintenance training for the temporary staff they plan to bring back for subsequent elections; and prepare for subsequent elections.

k) Judicial experience of members: The complaints adjudication process is essentially a judicial assessment and determination. The experience of a judge or possibly a senior lawyer is highly and probably uniquely relevant to the task. A panel of judges, retired fudges or senior lawyer will ensure that key aspects of the determination are professionally addressed.

1) Witness testimony: There is a tendency for political party officials to submit complaints on the basis of party agents' reports. The law, regulations or procedural rules should be clear that the election complaints authority must receive, directly and in person, the evidence of the person who witnessed the offense against the law or the 
Pilkada di Indonesia, tentu saja perkara dan sengketa yang timbul dalam konteks Pilkada membutuhkan lebih dari satu forum untuk menyelesaikannya. Pada titik inilah kemudian kelembagaan adjudikasi khusus menjadi relevan untuk diadakan.

Pengadilan Khusus Pilkada di Indonesia tentu tidak akan didesain sekuat seperti praktik di Uruguay, Brazil, maupun Costa Rica, bahkan harus dituangkan dalam Konstitusi dan dapat merambah cabang kekuasaan negara yang lain, namun lebih relevan bila melihat desain keserentakan yang bersifat musiman, maka didesain dengan sifat ad hoc, yang dibentuk secara khusus menjelang tahapan Pilkada serentak. Hal ini dikarenakan Pilkada serentak bukan merupakan kegiatan tahunan. Selain itu, Pengadilan Khusus Pilkada ini didesain sebagai pengadilan khusus di bawah lingkungan Peradilan Umum pada Mahkamah Agung yang menyatuatapkan segala bentuk sengketa dan perselisihan hasil Pilkada.
Dengan penyatuatapan di satu lembaga adjudikasi khusus, maka mekanisme tersebut akan mampu mengefisienkan penyelesaian sengketa Pilkada yang selama ini masih terpisah-pisah di beberapa lingkungan peradilan, yakni Peradilan Tata Usaha Negara untuk sengketa administrasi, Peradilan Umum untuk penyelesaian tindak pidana, dan untuk perselisihan hasil pada Pengadilan Tinggi yang ditunjuk oleh Mahkamah Agung. Dengan penyatuatapan upaya hukum di bawah Mahkamah Agung, sejatinya membuka peluang untuk dibentuknya suatu pengadilan khusus yang mampu menangani seluruh sengketa yang timbul dari tahapan Pilkada. Hal ini berbeda dengan Uruguay dan Brazil yang mendesain pengadilan pemilunya terpisah dari Supreme Court dan dianggap sebagai Judicial Power yang setingkat Supreme Court. Kewenangan pengadilan Khusus Pilkada Indonesia pun tidak seluas Uruguay dan Brazil yang menangani segala hal terkait pemilu mulai dari aspek administrasi, regulasi sampai yustisi. Pengadilan Khusus

violation of a regulation that founds the complaint, or who has personal knowledge to support the challenge to a candidate. A second hand report from a party official is hearsay and cannot be subjected to questioning.

m) Time limits: The law, regulations or procedural rules must establish time limits for submitting a challenge or complaint. Regarding the submission of complaints of offenses or violations, a short time limit of 24, 48 or 72 hours after the offense or violation was witnessed is sufficient. There is no need to allow time for a political decision to be made on whether to file a complaint. The question of time limits to which the election complaints authority must adhere is problematic. A limit of five or even fifteen days after receiving the complaint may result in the decision being abandoned, and encourage delay by the accused. Critical complaints may well involve complicated investigation. Speed is important, but not at the price of justice.

n) Reasonable sanctions: The election complaints authority must have the power to apply sanctions that are established by law; are reasonable; are proportional to the offense; are varied in range to meet different circumstances; are applied consistently; are not unduly limited by minima that remove discretion; include sanctions that are useful in cases where punitive action is suitable and also corrective, where possible; include disqualification of candidates or dismissal of elections staff for serious offenses; include a referral for criminal prosecution; and if applied, do not exclude additional punishment for included crimes on prosecution.

o) Publication of proper records: A summary of decisions taken should be issued on a regular basis during the challenges and complaints periods. This greatly adds Io the credibility of the process. On the other hand. expectations must be managed. As soon as time permits, a full report should be published, including the details of the more critical decisions. This is a task that the staff can complete for approval by the members, after final results. 
Pilkada hanya akan berfokus pada penyelesaian sengketa yang timbul dalam tahapan Pilkada.

Untuk konteks Indonesia, diharapkan desain kelembagaan dan hukum acara dari pengadilan khusus Pilkada akan mampu menjawab kebutuhan hukum akan sebuah mekanisme upaya hukum yang efisien dan efektif dalam tahapan Pilkada, sehingga tercipta Pilkada yang demokratis dan berkeadilan. Ada 2 (dua) poin pokok yang harus dikaji lebih lanjut terkait pembentukan pengadilan ini, yaitu desain kelembagaan pengadilan khusus Pilkada dan desain hukum acara pengadilan khusus Pilkada.

\section{a) Desain Kelembagaan}

Pengadilan Khusus Pilkada merupakan sebuah pengadilan khusus yang bersifat ad hoc di bawah lingkungan peradilan umum pada Mahkamah Agung. Nomenklatur pengadilan khusus diperkenankan oleh Undang-Undang Nomor 48 Tahun 2009 tentang Kekuasaan Kehakiman dengan pengaturan pengadilan khusus adalah pengadilan yang mempunyai kewenangan untuk memeriksa, mengadili dan memutus perkara tertentu yang hanya dapat dibentuk dalam salah satu lingkungan badan peradilan yang berada di bawah Mahkamah Agung yang diatur dalam undang-undang. ${ }^{93}$

Hal yang harus diperhatikan dari pengaturan tersebut adalah: Pertama, pengadilan khusus hanya dapat dibentuk dalam salah satu lingkungan badan peradilan yang berada di bawah Mahkamah Agung. Merujuk pada Undang-Undang Nomor 48 Tahun 2009 tentang Kekuasaan Kehakiman (UU Kekuasaan
Kehakiman), maka desain kelembagaan pengadilan khusus Pilkada harus dibentuk pada salah satu lingkungan peradilan di bawah Mahkamah Agung, yaitu di antara lingkungan peradilan umum, lingkungan peradilan agama, lingkungan peradilan militer, atau lingkungan peradilan tata usaha negara. ${ }^{94}$ Dengan memperhatikan kompleksitas Pilkada yang akan diselenggarakan serentak pada level kabupaten/ kota dan provinsi, maka lingkungan peradilan umum merupakan lingkungan peradilan yang paling relevan sebagai induk dari pengadilan khusus Pilkada.

Kedua, pengadilan khusus harus dibentuk dalam sebuah Undang-Undang. Pemahaman ini berangkat dari frasa "pengadilan khusus adalah pengadilan [...] yang diatur dalam undangundang". Dalam pendekatan ilmu perundangundangan, frasa tersebut adalah delegatie provisio dalam kaidah bij de wet geregeld, yang maknanya pembentukan pengadilan khusus dibentuk melalui Undang-Undang yang tidak harus mengatur khusus mengenai pengadilan khusus Pilkada. Pembentukan dan pengaturan mengenai pengadilan khusus Pilkada dapat disisipkan pada pengaturan dalam UU Pilkada.

Hallainyang harus diperhatikanadalah desain pengadilan khusus Pilkada sebagai pengadilan khusus ad hoc. Dalam hukum positif Indonesia, kelembagaan pengadilan ad hoc dikenal pada Pengadilan Hak Asasi Manusia (HAM) menurut Undang-Undang Nomor 26 Tahun 2000 tentang Pengadilan Hak Asasi Manusia (UU Pengadilan HAM $)^{95}$. Dengan menggunakan padanan definisi 
hakim ad hoc pada UU Kekuasaan Kehakiman, ${ }^{96}$ maka pengadilan khusus ad hoc dapat dimaknai pengadilan khusus yang bersifat sementara yang memiliki kompetensi absolut dan relatif di bidang tertentu untuk memeriksa, mengadili, dan memutus suatu perkara yang diatur dalam undang-undang. Desain kesementaraan pengadilan khusus Pilkada dikarenakan pengadilan hanya akan dibentuk pada saat menjelang proses Pilkada, yaitu paling lambat 6 (enam) bulan sebelum tahapan pertama penyelenggaraan Pilkada dimulai dan berakhir paling lambat 1 (satu) tahun setelah seluruh tahapan penyelenggaraan Pilkada selesai.

Terkait dengan tempat kedudukan pengadilan khusus Pilkada akan berada sesuai dengan kompetensi yang dimilikinya. Pengadilan khusus Pilkada untuk pemilihan Gubernur akan melekat pada Pengadilan Tinggi pada level provinsi, sedangkan untuk pemilihan Bupati/Walikota pengadilan khusus Pilkada akan melekat pada Pengadilan Negeri pada level Kabupaten/Kota. Dengan desain tersebut maka dapat dicapai efisiensi penyelesaian perkara, mengingat kasus Pilkada relatif banyak dengan tuntutan waktu penyelesaian secepat mungkin

Melihat aspek kompetensi, pengadilan khusus Pilkada didesain memiliki kewenangan untuk menangani segala sengketa yang timbul dalam proses Pilkada, mulai dari sengketa administrasi dan tindak pidana Pilkada, hingga perselisihan hasil Pilkada. Sedangkan untuk pelanggaran kode etik penyelenggara Pilkada, akan tetap menjadi kewenangan dari Dewan Kehormatan Penyelenggara Pemilihan Umum (DKPP). Walaupun Pilkada bukan lagi rezim pemilihan umum (Pemilu), namun merujuk pada Undang-Undang Nomor 15 Tahun 2011 tentang Penyelenggara Pemilihan Umum (UU Penyelenggara Pemilu) ${ }^{97}$, penyelenggaraan Pilkada merupakan domain kewenangan Komisi Pemilihan Umum (KPU). ${ }^{98}$ Dengan demikian, pelanggaran kode etik KPU sebagai penyelenggara Pilkada akan tetap dilaksanakan oleh DKPP.

Dengan keberadaan pengadilan khusus Pilkada, hal lain melekat adalah revitalisasi peran Badan Pengawas Pemilihan Umum (Bawaslu). Keseluruhan kompetensi pengadilan khusus Pilkada akan melibatkan peran dari Bawaslu Provinsi dan Panitia Pengawas Pemilihan Umum (Panwaslu) Kabupaten/Kota sebagai penyidik sekaligus penuntut umum dalam perkara pidana Pilkada, sehingga dengan demikian keberadaan pengadilan khusus Pilkada secara otomatis akan merevitalisasi peranan Bawaslu dalam Pilkada.

Adapun terkait komposisi hakim pada pengadilan khusus Pilkada, akan terdiri dari 2 (dua) orang hakim karier dan 1 (satu) orang akademisi hukum. Perspektif akademis diharapkan mampu memberikan perspektifyang memperkaya kualitas putusan dalam mengadili perkara Pilkada. Putusan yang dihasilkan oleh pengadilan khusus Pilkada bersifat final dan mengikat, sehingga diharapkan kepastian hukum dapat segera diperoleh oleh justiciable.

96 Pasal 1 angka 8 Undang-Undang Nomor 48 Tahun 2009 tentang Kekuasaan Kehakiman (Lembaran Negara Republik Indonesia Tahun 2009 Nomor 157, Tambahan Lembaran Negara Republik Indonesia Nomor 5076).

97 Pasal 1 angka 4 Undang-Undang Nomor 15 Tahun 2011 tentang Penyelenggara Pemilihan Umum (Lembaran Negara Republik Indonesia Tahun 2011 Nomor 101, Tambahan Lembaran Negara Republik Indonesia Nomor 5246).

98 Pasal 8 ayat (3) Undang-Undang Nomor 15 Tahun 2011 tentang Penyelenggara Pemilihan Umum (Lembaran Negara Republik Indonesia Tahun 2011 Nomor 101, Tambahan Lembaran Negara Republik Indonesia Nomor 5246). 


\section{b) Hukum Acara}

Sebagaimana telah dijelaskan di atas, bahwa pengadilan khusus Pilkada memiliki kompetensi menangani segala sengketa yang timbul dalam proses Pilkada, mulai dari sengketa administrasi dan tindak pidana Pilkada, hingga perselisihan hasil Pilkada. Pertama, sengketa administrasi Pilkada. Sengketa administrasi dapat lahir karena adanya keputusan tata usaha negara lembaga penyelenggara Pilkada yang merugikan masyarakat yang memiliki hak pilih dan/atau calon kepala daerah. Sengketa administrasi juga dapat dimungkinkan karena adanya pelanggaran terhadap keputusan tata usaha negara lembaga penyelenggara Pilkada oleh calon kepala daerah, seperti misalnya pelanggaran masa kampanye. Untuk sengketa yang lahir karena keputusan tata usaha negara lembaga penyelenggara Pilkada, maka pihak yang merasa terugikan dapat langsung mengajukan gugatan administrasi ke pengadilan khusus Pilkada. Sedangkan untuk perkara yang timbul karena adanya pelanggaran terhadap keputusan tata usaha negara lembaga penyelenggara Pilkada oleh calon kepala daerah, maka masyarakat harus melaporkan pada Bawaslu/Panwaslu disertai dengan buktibukti. Selanjutnya Bawaslu/Panwaslu akan membawa hal ini untuk diputus di pengadilan khusus Pilkada.

Kedua, tindak pidana Pilkada. Bila disinyalir terdapat tindak pidana Pilkada, laporan diajukan kepada Bawaslu untuk selanjutnya diselidiki dan disidik sebelum dilimpahkan pada proses penuntutan yang akan dilakukan pula oleh Bawaslu. Bawaslu dalam hal ini memiliki peran yang sangat besar dan vital, yaitu sebagai penyidik sekaligus penuntut umum. Ketentuan tersebut memang menyimpang dari diferensiasi fungsional yang ada dalam sistem peradilan pidana, namun hal tersebut sah untuk tetap didesain mengingat sifat khusus dari tindak pidana Pilkada. Setelah melalui proses penyidikan dan penuntutan dengan disertai bukti-bukti yang cukup, maka laporan tindak pidana Pilkada dapat diajukan untuk diperiksa di persidangan oleh hakim pada pengadilan khusus Pilkada.

Ketiga, perselisihan hasil Pilkada. Hasil Pilkada yang telah ditetapkan oleh KPU dapat diajukan ke pengadilan khusus Pilkada oleh calon kepada daerah yang mendalilkan ada selisih suara antara perhitungan KPU dengan perhitungan suara yang didalilkan merupakan suaranya. Inilah upaya hukum bagi calon kepala daerah untuk memohon pembatalan penetapan hasil penghitungan suara.

Keseluruhan proses penyelesaian sengketa dan perselisihan hasil Pilkada, harus mempertimbangkan kecepatan waktu demi menjaga tercederainya keadilan bagi para pihak. Oleh karena itu, jangka waktu antara laporan dengan pembacaan putusan Majelis Hakim juga harus dibatasi dalam jangka waktu tertentu, setidaktidaknya 3 (tiga) bulan.

\section{Penutup}

Sebagai penutup, pengadilan khusus Pilkada merupakan sebuah pembaharuan yang relevan untuk diadakan mengingat legal policy untuk menyelenggarakan Pilkada serentak pada tahun 2027. Terlebih, pengadilan khusus Pilkada ini telah dilaksanakan di beberapa negara yang berarti menunjukkan keberadaannya bukan suatu hal yang tabu. Akan tetapi, desain Pengadilan Khusus Pilkada di Indonesia tentu harus disesuaikan dengan kondisi negara, sehingga Penulis merumuskan bahwa desain yang sesuai adalah bersifat ad hoc, berada di bawah Mahkamah Agung, serta memiliki kewenangan untuk menangani 
segala sengketa yang timbul dalam proses Pilkada, mulai dari sengketa administrasi dan tindak pidana Pilkada, hingga perselisihan hasil Pilkada. Sedangkan untuk pelanggaran kode etik penyelenggara Pilkada, akan tetap menjadi kewenangan dari DKPP. Dengan keberadaan pengadilan khusus Pilkada, hal lain melekat adalah revitalisasi peran Bawaslu. Keseluruhan kompetensi pengadilan khusus Pilkada akan melibatkan peran dari Bawaslu Provinsi dan Panwaslu Kabupaten/Kota sebagai penyidik sekaligus penuntut umum dalam perkara pidana Pilkada, sehingga dengan demikian keberadaan pengadilan khusus Pilkada secara otomatis akan merevitalisasi peranan Bawaslu dalam Pilkada. Gagasan membentuk pengadilan khusus Pilkada ini merupakan sebuah gagasan awal yang harus diperkaya dan diperdalam untuk selanjutnya dapat diformulasikan secara utuh dan komprehensif mengenai pengadilan khusus Pilkada.

Sebagai saran, seluruh desain Pengadilan Khusus Pilkada ini sebaiknya dirumuskan dan dituangkan dalam peraturan perundangundangan, yang mana pembentukan pengadilan khusus dibentuk melalui Undang-Undang yang tidak harus mengatur khusus mengenai pengadilan khusus Pilkada. Pembentukan dan pengaturan mengenai pengadilan khusus Pilkada dapat disisipkan pada pengaturan dalam UU Pilkada. Pembaharuan untuk membentuk Pengadilan Khusus Pilkada patut segera dilaksanakan semata dalam rangka meningkatkan kualitas Pilkada bukan semata sebagai ritual politik, namun harus didorong sebagai upaya demokratisasi di daerah, namun lebih jauh menciptakan Pilkada yang berkeadilan.

\section{DAFTAR PUSTAKA}

\section{Buku}

Amiruddin dan Zainal Asikin, Pengantar Metode Penelitian Hukum (Jakarta: RajaGrafindo Persada, 2004).

Goodpaster, Gary, "The Rule of Law, Economic Development and Indonesia", dalam Timothy Lindsey (Ed.), Indonesia: Law and Society (Sydney: The Federation Press, 1999).

Jong, Martin De dan Virginie Mamadouh, "Two Contrasting Perspectives on Institutional Transplantation", dalam Martin De Jong, Konstantinos Lalenis, dan Virginie Mamadouh (Eds.), The Theory and Practice of Institutional Transplantation: Experiences with the Transfer of Policy Institutions (Dordrecht, The Netherlands: Kluwer Academic Publications, 2002).

Mahkamah Konstitusi, Prosiding Seminar Nasional Pemilihan Umum Kepala Daerah (Jakarta: Kepaniteraan dan Sekretariat Jendral Mahkamah Konstitusi Republik Indonesia, 2012).

Marzuki, Peter Mahmud, Penelitian Hukum (Jakarta: Kencana, 2005).

Pound, Roscoe, The Formative Era of American Law, (Boston: Little, Brown, and Co., 1938).

Ritaine, Eleanor Cashin, "Legal Engineering in Comparative Law - An Introduction", dalam Eleanor Cashin Ritaine (Ed.), Legal Engineering and Comparative Law (L'ingénierie juridique et le droit comparé) (Genève: Schulthess, 2009).

Smits, Jan M., "Legal Engineering in an Age of Globalisation: Is There a Future for Jurisdictional Competition?", dalam Eleanor Cashin Ritaine (Ed.),Legal Engineering and Comparative Law (L'ingénierie juridique et le droit comparé) (Genève: Schulthess, 2009).

Soekanto, Soerjono dan Sri Mamudji, Penelitian Hukum Normatif Suatu Tinjauan Umum (Jakarta: RajaGrafindo Persada, 2007).

Soemitro, Ronny Hanitijo, Metodologi Penelitian Hukum (Jakarta: Ghalia Indonesia, 1985).

Metodologi Penelitian Hukum dan Jurimetri (Jakarta: Ghalia Indonesia, 1988).

Staino, Sara, "Case Study: Uruguay: The Electoral Court-A Fourth Branch of Government?", dalam Alan Wall, et al., Electoral Management Design: The International IDEA Handbook (Stockholm: IDEA, 2006). 
Sumardjono, Maria S.W., Pedoman Pembuatan Usulan Penelitian: Sebuah Panduan Dasar (Jakarta: Gramedia, 2001).

Suriasumantri, Jujur S., IImu dalam Perspektif Moral, Sosial dan Politik: Sebuah Dialog tentang Keilmuan Dewasa Ini (Jakarta: Gramedia, 1986).

Valle, Rubén Hernández, "Case Study: Costa Rica: A Powerful Constitutional Body", dalam Alan Wall, et al., Electoral Management Design: The International IDEA Handbook (Stockholm: IDEA, 2006).

Vickery, Chad et al., Guidelines for Understanding, Adjudicating and Resolving Disputes in Elections (Washington DC.: USAID and IFES, 2011).

Waluyo, Bambang, Penelitian Hukum dalam Praktik (Jakarta: Sinar Grafika, 2002).

\section{Makalah/Artikel/Prosiding/Hasil Penelitian}

Ball, Harry V., dan Lawrence M. Friedman, "The Use of Criminal Sanctions in the Enforcement of Economic Legislation: A Sociological View", Stanford Law Review 17:2, (1965).

Beckstrom, John H., "Handicaps of Legal-Social Engineering in a Developing Nation", American Journal of Comparative Law 22: 4 (1974).

Damardono, A. Haryo dan Anita Yossihara, "Paripurna DPR Sahkan Pilkada Langsung" (Kompas, 20 Januari 2015).

Fauzi, Gamawan, "Keterangan Pemerintah Atas Rancangan Undang-Undang tentang Pemerintahan Daerah" (Rapat Kerja Pansus Rancangan Undang-Undang tentang Pemerintahan Daerah, Jakarta, 3 April 2012).

Kingsley, Jeremy J., "Legal Transplantation: Is This What the Doctor Ordered and are the Blood Types Compatible? The Application of Interdisciplinary Research to Law Reform in the Developing World - A Case Study of Corporate Governance in Indonesia", Arizona Journal of International and Comparative Law 21:2 (2004).

Langer, Máximo, "From Legal Transplants to Legal Translations: The Globalization of Plea Bargaining and the Americanization Thesis in Criminal Procedure", Harvard International Law Journal 45: 1 (2004).

Legrand, Pierre, "The Impossibility of Legal Transplants", Maastricht Journal of European and Comparative Law 4:2 (1997).

Petit, Denis, "Resolving Election Disputes in the OSCE Area: Towards a Standard Election Dispute
Monitoring System", (ODIHR Rule of Law Expert, Warsaw, 2000).

Tordoff, William, "Decentralisation: Comparative Experience in Commonwealth Africa", The Journal of Modern African Studies 32:4 (1994).

Torpman, Jan dan Fredrik Jörgensen, "Legal Effectiveness: Theoretical Developments Concerning Legal Transplants", Archiv Für Rechts und Sozialphilosophie 4 (2005).

\section{Internet}

Badan Legislasi Dewan Perwakilan Rakyat Republik Indonesia, "Rancangan Undang-Undang Republik Indonesia Nomor ... Tahun 2015 Perubahan Atas Undang-Undang Nomor 1 Tahun 2015 tentang Penetapan Peraturan Pemerintah Pengganti Undang-Undang Nomor 1 Tahun 2014 tentang Pemilihan Gubernur, Bupati, dan Walikota Menjadi Undang", http://www.dpr. go.id/dokakd/dokumen/BALEG-6-108aa1a82 bd52a99324db8b199f67794.pdf, (diakses 11 Maret 2015).

Country Studies US, "The Consolidation of Political Democracy", http://countrystudies.us/uruguay/ 13.htm, (diakses 4 Maret 2015).

Dewan Perwakilan Rakyat Republik Indonesia, "Paripurna DPR Setujui Revisi UU Pilkada dan RUU Pemda Menjadi UU", http://dpr.go.id/ berita/detail/id/9734, (diakses 11 Maret 2015).

Superior Electoral Court, "History of the Elections", http://english.tse.jus.br/history-of-theelections/the-empire, (diakses 2 Maret 2015).

Susila, Suryanta Bakti dan Agus Rahmat, "Akan Dibentuk Peradilan Khusus Sengketa Pilkada", http://politik.news.viva.co.id/news/ read/590742-akan-dibentuk-peradilan-khusussengketa-pilkada, (diakses 11 Maret 2015).

\section{Peraturan}

Constitution of Brazil 1988 (rev. 2014).

Constitution of Costa Rica 1949 (rev. 2011).

Constitution of Uruguay 1966 (reinst. 1985, rev. 2004).

Putusan Mahkamah Konstitusi Nomor 97/PUU$\mathrm{XI} / 2013$ perihal Pengujian Undang-Undang Nomor 12 Tahun 2008 tentang Perubahan Kedua Atas Undang-Undang Nomor 32 Tahun 2004 tentang Pemerintahan Daerah dan Undang-Undang Nomor 48 Tahun 2009 tentang Kekuasaan Kehakiman terhadap Undang- 


\section{R Junah HTSVINDING}

Media Pembinaan Hukum Nasional

Undang Dasar Negara Republik Indonesia Tahun 1945.

Surat Kementerian Dalam Negeri Republik Indonesia Nomor 120/4474/OTDA perihal Konfirmasi Data Akhir Masa Jabatan Kepala Daerah Tahun 2015, tanggal 29 Oktober 2014.

Undang-Undang Dasar Negara Republik Indonesia Tahun 1945.

Undang-Undang Nomor 26 Tahun 2000 tentang Pengadilan Hak Asasi Manusia (Lembaran Negara Republik Indonesia Tahun 2000 Nomor 208, Tambahan Lembaran Negara Republik Indonesia Nomor 4026).

Undang-Undang Nomor 48 Tahun 2009 tentang Kekuasaan Kehakiman (Lembaran Negara Republik Indonesia Tahun 2009 Nomor 157, Tambahan Lembaran Negara Republik Indonesia Nomor 5076).

Undang-Undang Nomor 15 Tahun 2011 tentang Penyelenggara Pemilihan Umum (Lembaran

\section{Volume 4, Nomor 1, April 2015}

Negara Republik Indonesia Tahun 2011 Nomor 101, Tambahan Lembaran Negara Republik Indonesia Nomor 5246).

Undang-Undang Nomor 1 Tahun 2015 tentang Penetapan Peraturan Pemerintah Pengganti Undang-Undang Nomor 1 Tahun 2014 tentang Pemilihan Gubernur, Bupati, dan Walikota Menjadi Undang-Undang (Lembaran Negara Republik Indonesia Tahun 2015 Nomor 23, Tambahan Lembaran Negara Republik Indonesia Nomor 5656).

Undang-Undang Nomor 8 Tahun 2015 tentang Perubahan Atas Undang-Undang Nomor 1 Tahun 2015 tentang Penetapan Peraturan Pemerintah Pengganti Undang-Undang Nomor 1 Tahun 2014 tentang Pemilihan Gubernur, Bupati, dan Walikota Menjadi Undang-Undang (Lembaran Negara Republik Indonesia Tahun 2015 Nomor 57. Tambahan Lembaran Negara Republik Indonesia Nomor 5678). 